\title{
Structural and Behavioural Changes in Rat Hippocampus Induced by Methotrexate and The potential ameliorative Effect of Alpha lipoic acid
}

Original Article

\author{
Amira E. Alsemeh, Amal Alshahat Ibrahim, Mohummad Omar Balhaj and \\ Heba Osama Mohammed
}

Department Anatomy and Embryology, Faculty of Medicine, Zagazig University, Egypt

\section{ABSTRACT}

Background: Methotrexate (MTX) is a chemotherapy drug associated with cognitive insufficiency in cancer patients treated with chemotherapy.. Alpha lipoic acid (ALA) has been referred to as the "universal antioxidant" because of its unique antioxidant properties.

Aim: To inspect the effect of MTX on the hippocampus and to correlate them with the cognition impairment and to assess the practical neuroprotective role of ALA on hippocampus.

Material and Method: Thirty two male adult albino were classified into four groups: control group (Physiologic saline), ALA group: (200 mg/kg orally for three weeks), MTX group: $(250 \mathrm{mg} / \mathrm{kg}$ ) as a single dose intraperitoneally injected and MTX +ALA group: rats were administrated a single dose of intraperitoneal injection of MTX (250 mg/ $\mathrm{kg})$ in the fourth day and were given ALA in a dose of $200 \mathrm{mg} / \mathrm{kg}$ orally for three weeks starting from the first day. All animals were subjected to Morris Water Maze testing to assess the hippocampus functions. At the end of the experiment, all animals anesthetized, cerebrum removed and the specimen subjected to histological procedures and biochemical examination.

Results: MTX caused impaired performance of Morris Water Maze of rats and biochemical changes significant decrease in oxidative enzymes and increase in malondialdehyde (MDA) tissue levels. Moreover, MTX caused histological changes in rat hippocampus in the form of degenerative and apoptotic neurons which confirmed by immnnohistochemical staining of caspase -3 and GFAP staining and morphometrical analysis of pyramidal cell layer thickness and pyramidal cell count. Co-administration of ALA with MTX significantly diminished the behavioral affection and biochemical changes in rat treated with MTX and ameliorated the histological changes of hippocampus tissue.

Conclusion: Our experimental results proved the harmful effect of MTX on hippocampus tissue that explained the cognitive impairment that associated with MTX and confirm the antioxidant and the antiapoptotic properties of ALA on hippocampus tissue.

Received: 01 October 2019, Accepted: 10 November 2019

Key Words: Alpha lipoic acid, hippocampus, methotrexate.

Corresponding Author: Amira Ebrahim Alsemeh, M.D, Department Anatomy and Embryology, Faculty of Medicine, Zagazig University, Egypt, Tel.: +20 1097746407, E-mail: Dr_Amira_2008@yahoo.com

ISSN: $1110-0559$, Vol. 43, No. 1

\section{INTRODUCTION}

The hippocampus is a part of limbic system. It is responsible for memory and learning. The blood-brain barrier protects the brain from some drugs but many chemotherapeutic drugs can affect its function by direct or indirect methods ${ }^{[1]}$. The laminar organization is similar in all the fields of the hippocampus. The CA regions are constructed of three clearly defined layers: polymorphic layer, pyramidal layer and molecular layer ${ }^{[2]}$. The chief cellular layer is called the pyramidal cell layer. This layer is closely packed in CA1 and loosely packed in CA2 and CA3. the laminar organization of CA2 is comparable to that of CA3 except for stratum lucidum present in CA3 only. CA2 is a narrow transitional field between CA3 and CA1. CA4 is the continuation o the CA 3 in the concavity of the dentate gyrus ${ }^{[3,4]}$.
Methotrexate (MTX) is a famous cytostatic agent used as common drug in combination chemotherapy for malignancies of lymphatic system. It improves the survival of patients with lymphoma or acute lymphoblastic leukemia (ALL) significantly, and effectively prevents the central nervous system leukemia relapse ${ }^{[5]}$ Also MTX is an anti-metabolite drug that has been found to have beneficial effects in a number of chronic inflammatory diseases ${ }^{[6]}$, it is critical for prophylaxis and treatment of sanctuary sites, including the $\mathrm{CNS}^{[7]}$.

However, intensified treatment protocols brought about a parallel increase in neurotoxicity ${ }^{[8]}$. Particularly, deficits in neurological and cognitive function are distressing complications of therapy for survivors, as these can last for years after treatment and affect learning or occupational performance ${ }^{[9,10]}$. 
The mechanism of neurotoxicity is likely through disruption of CNS folate homeostasis and/or direct neuronal damage .Studies have demonstrated that MTX neurotoxicity occurs by high dose or prolonged low-dose oral MTX. This neurotoxicity manifests with seizures, aphasia, encephalopathy and stroke-like symptoms. Excessive production of reactive oxygen species (ROS) has been implicated in MTX neurotoxicity ${ }^{[11,12]}$.

MTX negatively impacts the mitochondrial machinery and therefore generates excessive ROS, which has been implicated in its neurotoxicity ${ }^{[13,14]}$. ROS can initiate peroxidation of the cell membranes and damage cellular macromolecules leading to cell death ${ }^{[15,16]}$.

Another possible process that may contribute to the development of cognitive impairment is effect of MTX on cytokines.MTX is known to be capable of inducing an inflammatory cytokine response, which can lead to cytokine-induced sickness ${ }^{[17]}$.

Several reports have demonstrated that MTX changes memory ability and interferes with the neurogenesis process in terms of both physiology and pathology, which may cause breakdown of the memory system ${ }^{[18]}$.

Several reports have demonstrated that MTX causes changes to memory ability and interferes with the neurogenesis process in terms of both physiology and pathology, which may caused a breakdown of the memory system $^{[18]}$

ALA has been referred to as the "universal antioxidant" because of its unique antioxidant properties as a coenzyme present in the mitochondria, can eliminate pathogenic free radicals $^{[19]}$. ALA act as antioxidants both in hydrophilic and lipophilic environments of any cell or tissue type, as well as any subcellular compartment in the body ${ }^{[20]}$. In addition, it is one of the very few substances that can actually cross the blood/brain barrier and do not exhibit any serious side effects $^{[21]}$.

A different mechanisms of ALA's positive effects on cognitive function have been suggested, including improvement of memory-related signaling pathways, diminution of oxidative stress, and enhancing the mitochondrial function. ALA may also re-establish the activity of acetylcholinesterase and $\mathrm{Na}+, \mathrm{K}+$-ATPase. The activity of acetylcholinesterase was decreased in the cerebral corex, cerebellum, striatum, hippocampus, and hypothalamus in aged rats, while administration of ALA reversed the decrease in the activity in the discrete brain regions. Treatment with ALA also guarded against the cytotoxicity of cortical neurons induced by beta-amyloid or hydrogen peroxide ${ }^{[22]}$.

The objective of this study was to assess the potential neurotoxic effect of MTX on rat hippocampus and the possible ameliorating effect of ALA on adult rat.

\section{MATERIAL AND METHODS}

\subsection{Material \\ 2.1.1. Experimental Animals}

Thirty two healthy adult male Wistar albino rats weighing (12-14 weeks) 180 - $220 \mathrm{~g}$ were obtained and maintained at the Breeding Animal House of the Faculty of Medicine, Zagazig University, Egypt. Animals were kept for acclimatization in separate hygienic stainless steel cages at a controlled temperature $\left(23 \pm 2{ }^{\circ} \mathrm{C}\right)$ and humidity $(60 \pm 5 \%)$ in a (12:12 h light: dark cycle) artificially illuminated room, completely free from chemical contamination. They were fed standard laboratory diet and allowed free access for water. All animals were acclimatized to laboratory conditions for ten days prior to the commencement of experiments. All rats received humane care in compliance with Ethical Committee of Zagazig University and in accordance with the NIH Guidelines for the Care and Use of Laboratory Animals (No. ZU-IACUC/3/F/51/2019).

\subsubsection{Chemicals}

\subsubsection{Methotrexate drug}

MTX Was purchased from Maylan company in the form of vial ( $20 \mathrm{ml}$ each $\mathrm{ml}$ contains $25 \mathrm{mg})$.

\subsubsection{Alpha lipoic acid}

Alpha lipoic acid (Thiotacid or Thioctic acid) $300 \mathrm{mg}$ capsules were obtained from Eva-pharm pharmatheutical company - Egypt.

\subsubsection{Kits}

A malondialdehyde (MDA), a catalase (CAT) activity and superoxide dismutase (SOD) activity detection kits were purchased from Biodiagnostic, Cairo, Egypt-

\subsubsection{Experimental Design}

Thirty-two rats were randomly divided into four equal groups of eight rats ${ }^{[23]}$.

Control group: Physiological saline (PS) $\quad(0.09 \%$ $\mathrm{NaCl}$ ) solution was administered intraperitoneally (i.p.) in approximately the same volume as the drugs given to the other animals on the same day. The rats were provided with water and food ad libitum.

Alpha lipoic acid group (ALA treated group): Each rat was administrated ALA for three weeks orally $200 \mathrm{mg} / \mathrm{kg}^{[24]}$. Each rat received $40 \mathrm{mg}$ ALA. Each capsule contained 300 $\mathrm{mg}$ of ALA in the form of powder which was dissolved in $6 \mathrm{ml}$ of saline. So each milliliter of solution contained 50 $\mathrm{mg}$ of ALA. Therefore, each rat was administrated $0.80 \mathrm{ml}$ of dissolved ALA.

Methotrexate group (MTX treated group): each rat was administrated a single dose of intraperitoneal injection of MTX $(250 \mathrm{mg} / \mathrm{kg})$ on the first day Each rat was administrated $1.8-2 \mathrm{ml}^{[25]}$. 
Methotrexate and alpha lipoic acid group (MTX+ALA treated group ): each rat was administrated a single dose of MTX only $(250 \mathrm{mg} / \mathrm{kg})$ on the fourth day and ALA at a dose of $200 \mathrm{mg} / \mathrm{kg}$ orally for three weeks beginning from the first day ${ }^{[23]}$.

\subsection{Methods}

\subsubsection{Body weight}

At the end of each week, all rats were weighted by a digital electrical balance (Sartorius Goettingen type 140/ AG, W.Germany).

\subsubsection{Behavioral study (Morris Water Maze Testing)}

Morris Water Maze (302050-WM/1800, TSE systems, Germany) was utilized to appraise hippocampus-dependent spatial memory. The MWM formed of a white circular pool (180 $\mathrm{cm}$ diameter, $60 \mathrm{~cm}$ high) filled with water (30 $\mathrm{cm}$ depth) at $26 \pm 1^{\circ} \mathrm{C}$ and nearly divided into four equal quadrants: target quadrant, left quadrant, right quadrant and opposed quadrant. The water was prepared opaque with a mixture of white, thick, non- toxic milk. A circular escape platform (14 cm diameter) was flooded in water (1 $\mathrm{cm}$ below water surface) and located in the centre of target quadrant (Figure 1).

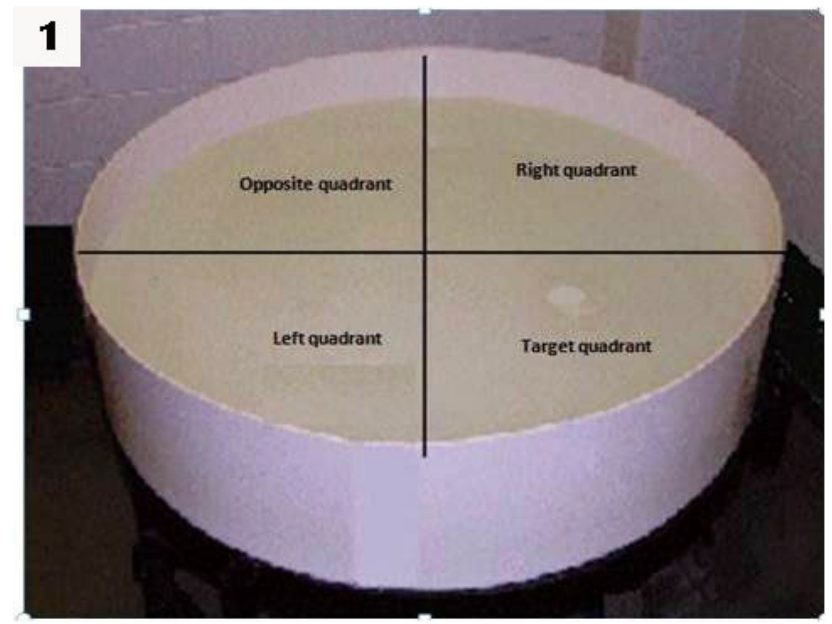

Fig. 1: Different virtual quadrants in Morris Water Maz

The rats behavior including latency to escape, (time spent in each quadrant) was observed by a video camera and analyzed. The rats were trained with the standard MWM learning protocol ${ }^{[26,27]}$. First, habituation to the training environment was performed at 14 days . Each rat was permitted to swim freely in the pool for 2 min without the presence of the platform. Next, training was carried out for 4 days (days $1-4$ of the MWM testing) and embraced four trials daily, therefore, each rat carried out a total of 16 attempts. The trial began when the rats were placed in the pool and facing the sidewall at one of the four quadrants, thus assembly four different starting points.

The latency to arrive at the submerged platform was traced as the escape latency. The rat was directed to the platform if it failed to escape within $60 \mathrm{sec}$ and was permitted to reside on the platform for $20 \mathrm{sec}$. consequently, on the 5thday of the MWM testing, rats were adjusted to a $120 \mathrm{sec}$ probe trial where the platform was detached from the pool. Each rat was located at the opposed side of the target quadrant (in which the platform had been situated) and the time spent in the target quadrant was recorded. Normal animals spend more time in the quadrant where the platform had been chiefly located (days 1-4) than in other quadrants.

Twenty four hours after the end of experiment, animals were anesthetized using intraperitoneal injection of thiopental $50 \mathrm{mg} / \mathrm{kg}$ body weight ${ }^{[28]}$. Afterward, laporatomy was done and the vault of each animal cranium was rapidly removed and cerebral cortex with reminants of meninges were exposed. The brain was carefully dissected out and divided in to two cerebral hemispheres. The first half of the hemisphers of all rats were fixed in $10 \%$ buffer formalin for $24 \mathrm{hr}$ and processed for examination by light microscope. The other hemisphers were homogenized in ice-cold phosphate buffer ( $\mathrm{pH} 8)$ at a concentration of $15 \%$ $(\mathrm{w} / \mathrm{v})$ to evaluate the oxidative stress biomarker

\subsubsection{Assay of tissue enzyme activity and lipid peroxidation}

The tissue samples were minced and homogenized, separately, in ice-cold sodium and, potassium phosphate buffer ( $\mathrm{pH} 8)$ at a concentration of $15 \%(\mathrm{w} / \mathrm{v})$ in Scientific Research Centre, Faculty of Medicine, Zagazig University. The homogenate was centrifuged at $110000 \times \mathrm{g}$ for $20 \mathrm{~min}$ at $4{ }^{\circ} \mathrm{C}$, and the resultant supernatant was used

Estimation of lipid peroxidation by determination of malondialdehyde (MDA) content according to Satoh ${ }^{[33]}$. Estimation of superoxide dismutase (SOD), catalase (CAT) and, reduced glutathione (GSH), were determined according to Nishikimi et al., Aebi, and Ellman ${ }^{[29,30,31]}$ respectively.

\subsubsection{Histological techniques by light microcopic examiination}

\section{Haematoxylin and eosin stain $(H \& E)$}

Hippocampus specimens were immediately fixed in $10 \%$ neutral buffered formalin for $24 \mathrm{~h}$, washed and dehydrated with ascending grade of alcohol, cleared in xylol, then embedded in paraffin. $5 \mu \mathrm{m}$ thick sections were prepared and stained with haematoxylin and eosin (H\&E) according to Bancroft and Layton ${ }^{[32]}$ for studying the histological structure of the rat hippocampus.

\section{Immunohistochemical stains}

Deparaffinized and hydrate deparaffinise sections were incubated for $20 \mathrm{~min}$ at $0.5^{\circ} \mathrm{c}$ in citrate buffer ( $\mathrm{pH} 6.0$ ) for antigen retrieval of the following proteins.

1-caspase-3 antibody (cystiene aspartic acid specific protease-3) (Wu et al., ${ }^{[25]}$ caspase- 3 is an effector marker for apoptosis known to be increased in neurodegenerative diseases. Rabbit monoclonal antibody of IgG type against 
caspase 3 (dilution 1:100) delivered from Lab Vision Laboratories. Apoptotic cells observed with yellow to brown discoloration.2-Glial fibrillar acidic protein (GFAP) is the most commonly used method to examine the distribution of astrocytes and their response to neural degeneration or injury ${ }^{[33]}$. The modified Avidin - Biotin immunoperoxidase technique for GFAP was applied to demonstrate the astrocytes. Primary anti GFAP antibody goat polyclonal IgG, anti-rat produced by DakoCytomation was used. Working dilution was 1: 1000.. GFAP containing cells (astrocytes) appeared brown ${ }^{[34]}$. The positive results were indicated by brown coloration of the cell membrane and cytoplasm of the astrocytes. All stained slides were analyzed by light microscopy (LEICA ICC50 W) in Image Analysis Unit of Anatomy and Embryology department .

\subsubsection{Morphometrical study}

For morphometric study, six rats were utilized per group by using image analyzer (the Image $J$ software plugin) in Anatomy Department - Zagazig University as follow:

1. Percepetive H\&E stained slides of each group were analyzed to measure the thickness of the pyramidal cell layer (PCL) of CA CA1,CA3 and CA4.

2. Percepetive H\&E stained sections of each group were analyzed for pyramidal cell counting in PCL of CA1,CA3 and CA4 and by using point selection at the objective lens of $40 x$.

3. Percepetive Caspase-3 immunohistochemical stained sections of each group were analyzed for calculating the immunopositive cells in PCL by using point selection at the objective lens of $40 \mathrm{x}$.

4. Percepective GFAP immunohistochemical stained sections of each group were analyzed to estimate the area percent of positive immuno reaction for GFAP which was done after image splitting. Images were splitted into RGB stacks, then red stack was adjusted to threshold to mark it with a binary mask. Then the percent area in relative to the field was calculated at the objective lens of $40 x$.

\subsubsection{Statistical analysis}

Continuous variables were expressed as the mean $\pm \mathrm{SD}$ as the data exhibited normal distributions (parametric). Normality was checked by the KolmogorovSmirnov test. One-way ANOVA was used to detect significant differences between groups. Post hoc Tukey's test was performed for multiple comparisons between groups. The differences were considered significant at $P<0.05$. All statistical comparisons were two tailed. All statistical calculations were carried out using Graph pad Prism software, version 5.0 (Graph Pad Software, San Diego, CA, USA

\section{RESULTS}

The control group and ALA treated group showed no detectable differences between them in body weight, behaviour changes, biochemical changes or histological changes; therefore, they were considered as one group, called the control group

\subsection{Sign of toxicity and body weight measurement}

Rats treated with MTX revealed loss of weight, decrease in feeding with mild diarrhea during the 1st week of experiment. Two rats died in the MTX-treated group on the $6^{\text {th }}$ day of administration. So, to standardized our results of statistical analysis we utilized 6 rats per group. We calculated the intial body weight at the first day of the study and at the end of the $1^{\text {st }}, 2^{\text {nd }}$ and $3^{\text {rd }}$ weeks. At the end of 1st week, MTX treated rats exhibited significantly lower body weight compared to control and MTX +ALA treated rats but the MTX +ALA treated rats exhibited significant different from the control rats. At the end of the $2^{\text {nd }}$ week, all animals started to regain the body weight but the difference in body weight between the different groups still was significant. At the end of the $3^{\text {rd }}$ week, there were increase in the body weight in all groups but the MTX treated rats still exhibited significant difference from the control and MTX+ALA treated rats. These findings are presented in (Figure 2 and Table 1).

\subsection{Changes on rat memory and learning ability}

To evaluate the effect of MTX on memory and the learning ability of rats and to confirm the protective role of ALA, we subjected the rats to MWM testing As presented in (Figure $3 a, b)$ which revealed no significant differences in the escape latency between the all experimental groups on the first day of hidden plate form.

In MTX group, the latency to reach the hidden plat form reduced significantly from the first day to the $2^{\text {nd }}$ day. but in control and the MTX+ALA treated group, it was significantly reduced in all days from 1 st to $4^{\text {th }}$ day .

On the $4^{\text {th }}$ day of MTX-treated rats appeared to perform worse than control rats; the escape latency was significantly higher (the time to reach the hidden platform was greater) among the MTX-treated rats than among the control rats and the MTX+ALA-treated rats. In contrast, the escape latency of MTX+ALA-treated rats was significantly lower than that of MTX rats but was still significantly different from that of control rats $(P<0.05)$. These findings are presented in (Figure $3 \mathrm{a}, \mathrm{b}$ ).

To observe memory recovery, we evaluated the time that the rats spent in the quadrant with the fixed platform during the probe trial. The MTX-treated rats spent significantly less time in this quadrant than the control rats. In contrast, the MTX +ALA-treated rats spent significantly more time in the fixed platform quadrant than the control rats. but still 
exhibited a significant difference from the control rats as presented in (Figure 4 and Table2).

\subsection{Biochemical results}

\section{Lipid peroxidation and antioxidant enzyme activity}

SOD and CAT and GSH values were significantly decrease in the MTX treated group $(2.33 \pm 0.14 \mathrm{u} / \mathrm{g}$, $0.66 \pm 0.057 \mathrm{u} / \mathrm{g}$, and $0.89 \pm 0.51 \mathrm{nmol} / \mathrm{g}$ ) respectively than in the control group $(4.19 \pm 0 . .72 \mathrm{u} / \mathrm{g}, 1.73 \pm 0.071 \mathrm{u} / \mathrm{g}$ and $2.31 \pm 0.13 \mathrm{nmol} / \mathrm{g}$ ) respectively. However, SOD and CAT and GSH values in the MTX +ALA treated group $(3.25 \pm 0.20 \mathrm{u} / \mathrm{g}$ and $1.24 \pm 0.12 \mathrm{u} / \mathrm{g}$ and $1.918 \pm 0.14$ $\mathrm{nmol} / \mathrm{g}$ ) respectively were significantly higher than those in the MTX group. However, SOD and CAT levels still significantly different from those in the control group. In contrast, GSH exhibited a non significant different from the control group. Meanwhile, MDA values were significantly higher in the MTX treated group $(30.09 \pm 1.06 \mathrm{~nm} \mathrm{ol} / \mathrm{g})$ than in the control group $(11.07 \pm 0.57)$. In contrary, co administration of ALA along with the MTX significantly decreased the MDA level $(16.92 \pm 2.15 \mathrm{~nm} \mathrm{ol} / \mathrm{g})$.but still significantly different from those in the control group $(4.40 \pm 0.46 \mathrm{nmol} / \mathrm{g})$ (Figure 5 and Table 3).

\subsection{Histological results}

\subsubsection{Haematoxylin and eosin stain}

\section{Control group}

Examination of parasagittal sections of rats hippocampi of the control group and ALA groups revealed that the hippocampal formation was formed of the hippocampus proprius (CA) and the DG. The CA was further subdivided into four regions (CA1, CA2, CA3 and CA4) consisting of 1- Stratum pyramidal (pyramidal cell layer, PCL) 2- Stratum oriens (Polymorphic cell layer, POL) deep to the PCL 3Stratum radiatum 4-Stratum Lacunosum was occupied by the distal apical dendrites 5- stratum moleculare, Molecular layer, ML). A narrow cellular zone (the stratum lucidum, SL) was present only in CA3. The dentate gyrus (DG) was observed as coiled structure with opened concave part directed to hippocampus proprius. The DG consisted of three layers, stratum molecular (molecular cell layer, ML), stratum granulae (granular cell layer, GCL) and stratum multiforme (Polymorphic cell layer, POL). (Figure 6). As CA2 was considered as a narrow transitional field between CA3 and CA1, we described the layers of CA1,CA3,CA4 which were arranged in three layers as follows:

POL: This layer contained either deeply or lightly stained glial cells. PCL: which is the main cell layer contained small tightly packed pyramidal cells in CA1 and large loosely packed pyramidal cells in CA3 and CA4. These cells were triangular in shape had a large rounded vesicular nuclei with prominent nucleoli. Within the PCL, small glial cells with either deeply or lightly stained rounded to oval nuclei and characteristic perinuclear halo were observed. Blood vessels could be seen.
(Figures 7,8,9). SL: was a narrow zone occupied by mossy fibers of DG present only in CA3 (Figure 8). ML: contained branched apical dendrities of PCL and widely spaced cells. Many of them were small with rounded deeply stained nuclei. Probable mitotically dividing cells could also be observed. large blood vessel with perivascular glial cells were also seen. (Figures 7,8,9).

\section{MTX treated group}

Parasagittal section of rat hippocampus of MTX treated group showed DG : dentate gyrus CA1: cornu ammonis 1, CA2: cornu ammonis2, CA3: cornu ammonis3, CA4: cornu ammonis4, lateral ventricle, hippocampus sulcus: choroid plexus (Figure 10).

CA1 of MTX treated group showed the three layers: POL, had lightly or deeply stained nuclei with widely pericellular space. PCL, with few normal pyramidal cells and others pyramidal cells had large lightly stained nuclei most pyramidal cells were degenerated with shrunken deeply stained elongated nuclei or pyknotic nuclei with pericellular vaculation. Perineural glail cells can be observed around the degenerated neurons. ML, with deeply stained glail cells (Figure 11).

CA3 of MTX treated group showed its three layers: POL, had deeply stained nuclei and glial mitotic cell division o. PCL had few cells with large lightly stained nuclei $(\mathrm{Pa})$ and most cells were degenerated with shrunken deeply stained elongated nuclei or pyknotic nuclei with pericellular vaculation. Perineural glail cells could be observed. ML had either deeply or lightly stained nuclei (Figure 12). Other section of MTX treated group showed that most cells of PCL were degenerated with shrunken deeply stained elongated nuclei or pyknotic nuclei with pericellular vaculation. POL had deeply or lightly stained nuclei and congested dilated blood vessel (Figure 13).

CA4 of MTX treated group showed its three layers: POL had either deeply or lightly stained nuclei with widely pericellular space. Blood vessel could be seen PCL had some pyramidal cells with large lightly stained nuclei. Other cells with shrunken deeply stained elongated nuclei or pyknotic nuclei with pericellular vaculation. ML with widely spaced and deeply stained glail cells (Figure 14)

\section{$M T X+A L A$ treated group}

Parasagittal section of rat hippocampus of MTX +ALA treated group showed DG: Dentate Gyrus, CA1: Cornu Ammonis1, CA2: Cornu Ammonis2, CA3: Cornu Ammonis3, CA4: Cornu Ammonis4, lateral ventricle, hippocampus sulcus, choroid plexus (Figure 15)

CA1 of MTX +ALA treated group showed its three layers: ML had either deeply stained or lightly stained glial cells nuclei. PCL had slightly dispersed pyramidal cells, most of them were normal and few pyramidal cells had large lightly stained nuclei and others had degenerated cells with shrunken deeply stained elongated nuclei or pyknotic nuclei with pericellular vaculation. POL had glial 
cells with deeply stained nuclei and wide pericellular space (Figure 16).

CA3 of MTX + ALA treated group showed its three layers: POL and PCL with most pyramidal cells were normal and few degenerated cells with shrunken deeply stained nuclei or pyknotic nuclei with pericellular vaculation were noticed. Blood vessel and perineural gliall cells can be observed. ML had glial cells with deeply stained nuclei and wide pericellular space (Figure 17).

CA4 of MTX +ALA treated group showed its three layers: ML had glial cells with either deeply or lightly stained nuclei with wide pericellular space PCL showed most pyramidal cells were normal and few degenerated cells with shrunken deeply stained nuclei with pericellular vaculation were observed. Perineural glail cells. could be seen. POL had glial cells with deeply stained nuclei (Figure 18)

\subsubsection{Immunohistochemical results}

\subsubsection{Caspase -3 immunostaining results}

The hippocampus was immunohistochemically stained with anti-caspase 3 antibody to clarify the localization of apoptotic neurons in CA regions (CA1,CA3 and CA4) in all experimental groups. The immune positive reaction was localized in the cytoplasm of apoptotic neurons. In the control group the neurons revealed negative immunoreaction in the $\mathrm{CA}$ regions (CA1,CA3 and CA4) of hippocampus (Figure 19). However, in the MTX treated group, abundant caspase immunopositive neurons were detected in the $\mathrm{CA}$ regions (CA1,CA3 and CA4) of hippocampus (Figure 20). Whereas fewer caspase-3 immunopositive neurons were observed in CA regions (CA1,CA3 and CA4) of hippocampus of the MTX + ALA treated group (Figure 21).

\subsubsection{GFAP immunostaining results}

The hippocampus was immunohistochemically stained with the anti-GFAP antibody to clarify the response of astrocytes to the neural degeneration in the different experimental groups. In the control group, the astrocytes were detected among the pyramidal cells in CA1,CA3 and CA4; however, many of them were seen dispersed among the molecular layer. Astrocytes had many ramifying processes passing in between the neuronal cells (Figure 22). However, in MTX treated group there were abundant GFAP positive staining of the cytoplasm and the processes of astrocytes. They were apparently increased in number and appeared larger with multiple long thick processes (Figure 23). In MTX+ALA treated group showed astrocytes with large ,multiple thin long processes (arrows).with thin ramified processes inbetween the pyramidal cells in CA1,CA3,CA4 regions. Many of astrocytes are seen dispersed among the molecular and the polymorphic layers (Figure 24).

\subsection{Morphometrical results}

\subsubsection{Pyramidal cell count}

Statistical analysis of pyramidal cell count showed a significant decrease in pyramidal cell count of PCL in the different areas of CA1 and CA4 and CA3 of the MTX treated group compared to the control group $(P \leq 0.05$ and $\geq 0.001)$. On the other hand, co administration of AlA with MTX revealed a significant increase in pyramidal cell count in different areas of CA when compared to the MTX group but still exhibited a significant difference from the control group $(P \geq 0.05)$ (Figure 25 and Table 4).

\subsubsection{Pyramidal Cell Layer Thickness}

Statistically analysis of PCL thickness revealed a significant decrease in pyramidal layer thickness of MTX treated group in CA1,CA3 and CA4 areas compared to the control group and MTX +ALA treated $(P \leq 0.05)$ (Figure 26 and Table 5).

\subsubsection{Caspase -3 Immunohistochemical Staining}

The quantitative analysis of the number of caspase immune-positive neurons for in CA1, CA4, CA 3 revealed a significant increase in the number of immune positive neurons in MTX treated group compared to the control group. Coadminstration of the ALA in concomitant with the MTX exhibited a significant decrease in the number of immunopositive neurons compared to MTX treated group and revealed a non significant difference from the control group in CA1,CA4 but still exhibited a significant difference from the control group in CA3 area (Figure 27 and Table 6).

\subsubsection{GFAP Immunohistochemical staining}

Statistical analysis of area \% of GFAP reactivity revealed a significant increase in the area $\%$ of reactivity in relation to the microscopic field in MTX treated group compared to control group in CA1,CA4 and a highly significant in $\mathrm{CA} 3$ area $(P \leq 0.05)$

In group treated with MTX + ALA, there was a significant decrease in the area \% of GFAP reactivity in relation to the microscopic field compared to MTX treated group $(p \geq 0.05)$. However, there was still a significant difference compared to control group in CA1, CA3, CA4 $(P \leq 0.05)$ (Figure 28 and Table 7) 
Table 1: Comparison between different studied groups regarding weight loss of rats

\begin{tabular}{cccccccc}
\hline & Weight & N & Mean & Std. Deviation & Std. Error & Minimum & Maximum \\
\hline \multirow{3}{*}{$1^{\text {st }}$ day weight } & Control group & 6 & 204.5 & 6.44 & 2.63 & 195 & 210 \\
& MTX treated group & 6 & 204.5 & 5.23 & 2.13 & 198 & 210 \\
& MTX + ALA treated group & 6 & 202.2 & 9.28 & 3.79 & 190 & 215 \\
& Control group & 6 & 215 & 10.49 & 4.28 & 200 & 230 \\
End of $1^{\text {st }}$ week & MTX treated group & 6 & 174.3 & 6.89 & 2.81 & 165 & 184 \\
& MTX +ALA treated group & 6 & 195.8 & 10.12 & 10.21 & 180 & 210 \\
& Control group & 6 & 225 & 16.83 & 6.87 & 200 & 242 \\
End of $2^{\text {nd }}$ week & MTX treated group & 6 & 184 & 5.03 & 2.05 & 179 & 190 \\
& MTX +ALA treated group & 6 & 204 & 14.29 & 5.83 & 187 & 221 \\
& Control group & 6 & 232.3 & 5.46 & 2.23 & 226 & 240 \\
End of $3^{\text {rd }}$ week & MTX treated group & 6 & 198.5 & 15.54 & 6.34 & 180 & 220 \\
& MTX +ALA treated group & 6 & 215.3 & 11.08 & 4.52 & 228 & 228 \\
\hline
\end{tabular}

Table 2: Comparison between different studied groups regarding the time spend in target quadrant over 60 seconds

\begin{tabular}{|c|c|c|c|c|c|c|c|}
\hline & & $\mathrm{N}$ & Mean & SD & Std. Error & Minimum & Maximum \\
\hline \multirow{3}{*}{$\begin{array}{l}\text { Probe trail } \\
\text { of MWM }\end{array}$} & Control group & 6 & 30.93 & 2.269 & 0.9262 & 28.00 & 34.00 \\
\hline & MTX treated group & 6 & 18.00 & 3.688 & 1.506 & 12.00 & 23.00 \\
\hline & MTX +ALA treated group & 6 & 24.67 & 3.670 & 1.498 & 21.00 & 30.00 \\
\hline
\end{tabular}

Table 3: Comparison between different studied groups regarding the oxidative stress biomarkers

\begin{tabular}{|c|c|c|c|c|c|c|c|}
\hline Oxidative stress biomarkers & Groups & $\mathrm{N}$ & Mean & Std. Deviation & Std. Error & Minimum & Maximum \\
\hline \multirow{3}{*}{ SOD } & Control group & 6 & 4.185 & 0.1750 & 0.0714 & 3.900 & 4.400 \\
\hline & MTX treated group & 6 & 2.330 & 0.3390 & 0.1384 & 1.980 & 2.950 \\
\hline & MTX +ALA treated group & 6 & 3.253 & 0.4914 & 0.2006 & 2.760 & 4.110 \\
\hline \multirow{3}{*}{ CAT } & Control group & 6 & 1.733 & 0.1729 & 0.07060 & 1.440 & 1.940 \\
\hline & MTX treated group & 6 & 0.6580 & 0.1269 & 0.05675 & 0.4980 & 0.8200 \\
\hline & MTX + ALA treated group & 6 & 1.242 & 0.2800 & 0.1143 & 0.9600 & 1.740 \\
\hline \multirow{3}{*}{ GTH } & Control group & 6 & 2.307 & 0.3172 & 0.1295 & 2.010 & 2.880 \\
\hline & MTX treated group & 6 & 0.8893 & 0.1241 & 0.0506 & 0.7560 & 1.100 \\
\hline & MTX + ALA treated group & 6 & 1.918 & 0.3610 & 0.1474 & 1.730 & 2.750 \\
\hline \multirow{3}{*}{ MDA } & Control group & 6 & 11.07 & 1.385 & 0.5653 & 9.230 & 13.23 \\
\hline & MTX treated group & 6 & 30.09 & 2.597 & 1.060 & 25.27 & 30.09 \\
\hline & MTX +ALA treated group & 6 & 16.92 & 5.272 & 2.152 & 11.49 & 16.92 \\
\hline
\end{tabular}

Table 4:Comparison between the different experimentalgroups regarding pyramidal cells count (PCL)

\begin{tabular}{|c|c|c|c|c|c|c|c|}
\hline & & $\mathrm{N}$ & Mean & Std. Deviation & Std. Error & Minimum & Maximum \\
\hline \multirow{3}{*}{ CA1 } & Control group & 6 & 41.33 & 6.802 & 2.777 & 30.00 & 50.00 \\
\hline & MTX treated group & 6 & 21.00 & 4.940 & 2.017 & 14.00 & 29.00 \\
\hline & MTX + ALA treated group & 6 & 35.33 & 3.870 & 1.585 & 30.00 & 40.00 \\
\hline \multirow{3}{*}{ CA3 } & Control group & 6 & 25.67 & 5.989 & 2.445 & 19.00 & 35.00 \\
\hline & MTX treated group & 6 & 7.40 & 1.720 & 0.702 & 5.00 & 9.40 \\
\hline & MTX + ALA treated group & 6 & 18.33 & 1.633 & 0.666 & 16.00 & 20.00 \\
\hline \multirow{3}{*}{ CA4 } & Control group & 6 & 30.00 & 7.155 & 2.921 & 19.00 & 40.00 \\
\hline & MTX treated group & 6 & 20.50 & 5.541 & 2.262 & 14.00 & 29.00 \\
\hline & MTX +ALA treated group & 6 & 28.17 & 3.371 & 1.376 & 23.00 & 33.00 \\
\hline
\end{tabular}


Table 5:Comparison between different experimental groups regarding thickness of Pyramidal cell layer (PCL)

\begin{tabular}{|c|c|c|c|c|c|c|c|}
\hline & & $\mathrm{N}$ & Mean & Std. Deviation & Std. Error & Minimum & Maximum \\
\hline \multirow{3}{*}{ CA1 } & Control group & 6 & 55.47 & 2.48 & 1.01 & 52.85 & 38.81 \\
\hline & MTX treated group & 6 & 46.37 & 5.10 & 2.08 & 37.67 & 50.11 \\
\hline & MTX +ALA treated group & 6 & 54.22 & 3.85 & 1.57 & 50.57 & 60.33 \\
\hline \multirow{3}{*}{ CA3 } & Control group & 6 & 45.23 & 6.54 & 2.67 & 37.92 & 55.62 \\
\hline & MTX treated group & 6 & 32.72 & 1.75 & 0.71 & 30.44 & 34.97 \\
\hline & MTX +ALA treated group & 6 & 40.86 & 5.35 & 2.18 & 33.34 & 47.56 \\
\hline \multirow{3}{*}{ CA4 } & Control group & 6 & 50.31 & 3.097 & 1.265 & 47.28 & 55.03 \\
\hline & MTX treated group & 6 & 44.00 & 3.386 & 1.384 & 41.28 & 49.85 \\
\hline & MTX +ALA treated group & 6 & 49.20 & 4.264 & 1.741 & 45.46 & 53.11 \\
\hline
\end{tabular}

Table 6: Comparison between the different experimental groups regarding the number of immunopositive cells to caspase -3

\begin{tabular}{|c|c|c|c|c|c|c|c|}
\hline & & $\mathrm{N}$ & Mean & Std. Deviation & Std. Error & Minimum & Maximum \\
\hline \multirow{3}{*}{ CA1 } & Control group & 6 & 12.64 & 1.96 & 0.801 & 10.02 & 14.92 \\
\hline & MTX treated group & 6 & 31.55 & 4.16 & 1.699 & 28.42 & 39.36 \\
\hline & MTX +ALA treated group & 6 & 19.07 & 2.17 & 0.88 & 16.23 & 22.36 \\
\hline \multirow{3}{*}{ CA3 } & Control group & 6 & 0.500 & 0.836 & 0.341 & 0.00 & 2.00 \\
\hline & MTX treated group & 6 & 16.50 & 3.017 & 1.232 & 12.00 & 21.00 \\
\hline & MTX + ALA treated group & 6 & 5.833 & 2.317 & 0.945 & 3.00 & 9.00 \\
\hline \multirow{3}{*}{ CA4 } & Control group & 6 & 12.06 & 2.586 & 1.056 & 7.489 & 14.89 \\
\hline & MTX treated group & 6 & 29.02 & 3.264 & 1.332 & 24.44 & 32.20 \\
\hline & MTX +ALA treated group & 6 & 18.53 & 8.181 & 3.340 & 2.941 & 26.04 \\
\hline
\end{tabular}

Table 7: Comparison between the different experimental groups regarding Area \% of GFAP

\begin{tabular}{|c|c|c|c|c|c|c|c|}
\hline \multicolumn{2}{|c|}{ Area $\%$ of GFAP } & \multirow{2}{*}{$\frac{N}{6}$} & \multirow{2}{*}{$\begin{array}{l}\text { Mean } \\
12.64\end{array}$} & \multirow{2}{*}{$\begin{array}{c}\text { Std. Deviation } \\
1.96\end{array}$} & \multirow{2}{*}{$\begin{array}{c}\text { Std. Error } \\
0.801\end{array}$} & \multirow{2}{*}{$\begin{array}{c}\text { Minimum } \\
10.02\end{array}$} & \multirow{2}{*}{$\frac{\text { Maximum }}{14.92}$} \\
\hline & Control group & & & & & & \\
\hline \multirow[t]{3}{*}{ GFAP- CA1 } & MTX treated group & 6 & 31.55 & 4.16 & 1.699 & 28.42 & 39.36 \\
\hline & MTX + ALA treated group & 6 & 19.07 & 2.17 & 0.88 & 16.23 & 22.36 \\
\hline & Control group & 6 & 13.59 & 1.83 & 0.74 & 10.96 & 15.82 \\
\hline \multirow[t]{3}{*}{ GFAP - CA3 } & MTX treated group & 6 & 37.9 & 6.43 & 2.62 & 32.91 & 47.40 \\
\hline & MTX +ALA treated group & 6 & 21.24 & 2.78 & 1.24 & 17.57 & 24.57 \\
\hline & Control group & 6 & 12.06 & 2.586 & 1.056 & 7.489 & 14.89 \\
\hline \multirow[t]{2}{*}{ GFAP - CA4 } & MTX treated group & 6 & 29.02 & 3.264 & 1.332 & 24.44 & 32.20 \\
\hline & MTX +ALA treated group & 6 & 18.53 & 8.181 & 3.340 & 2.941 & 26.04 \\
\hline
\end{tabular}

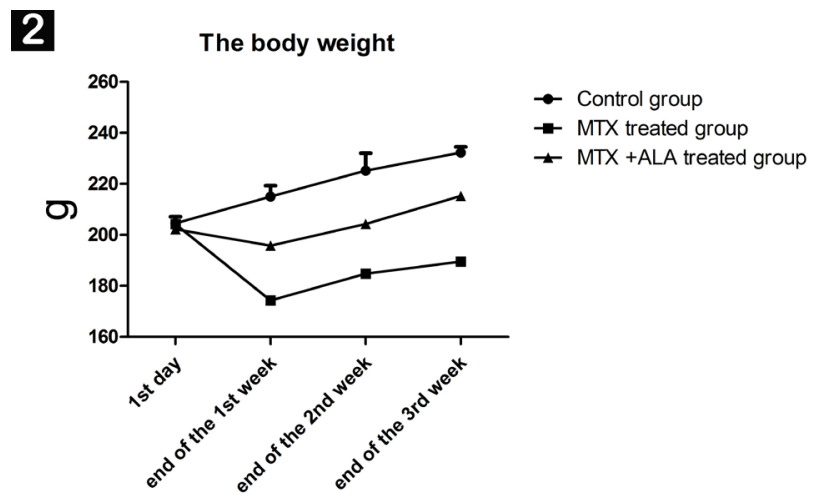

Fig. 2: Line graph showing thecomparison between the different studied groups regarding weight loss of rats 
$3 \mathbf{a}$ Hidden plateform

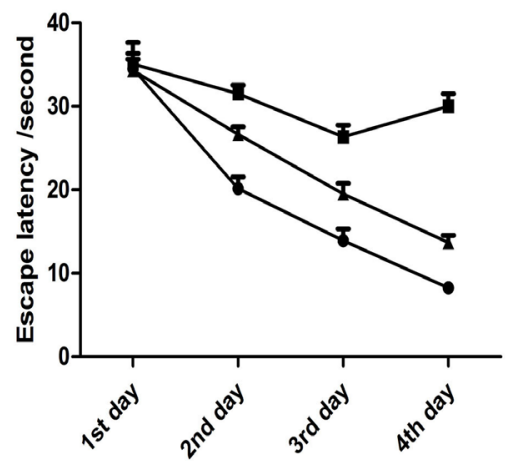

36 Hidden plateform

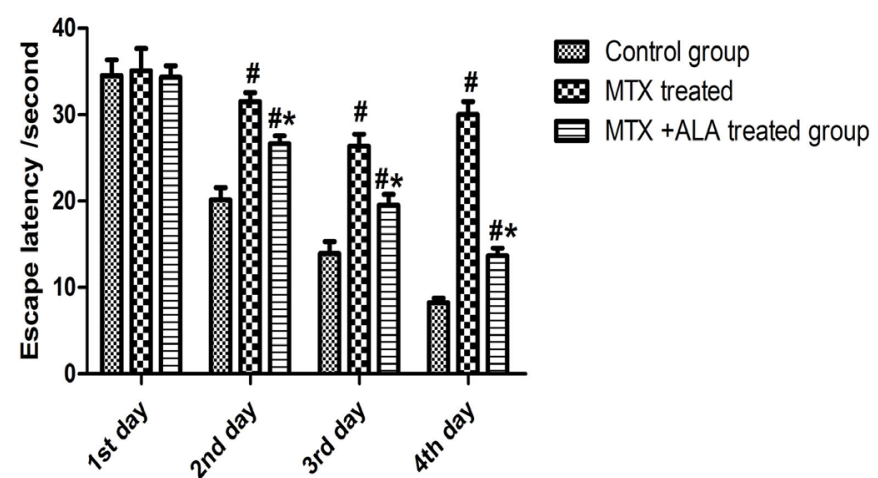

Fig. 3: Line graph (a) and Bar chart (b) showing the escape latency to reach the hidden platform in all experimental groups which reveling no significant differences between the all experimental groups on the first day. On 4th day, there are significant increase in escape latency in the MTX treated rats where the rats spent more time to reach the hidden platform than control group and MTX +ALA treated rats. In contrary, MTX + ALA treated rats revealed significant decrease in escape latency compared to MTX rats but still exhibited significant difference from the control i. Statistical analysis was performed using one-way ANOVA, followed by Tukey's post hoc test. Values are represented as the mean $\pm \mathrm{SE}(\mathrm{n}=6)$. \# Significant difference compared to the control group, $\mathrm{P}<0.05$. ${ }^{*}$ Significant difference compared to the MTX group, $\mathrm{P}<$ 0.05 .

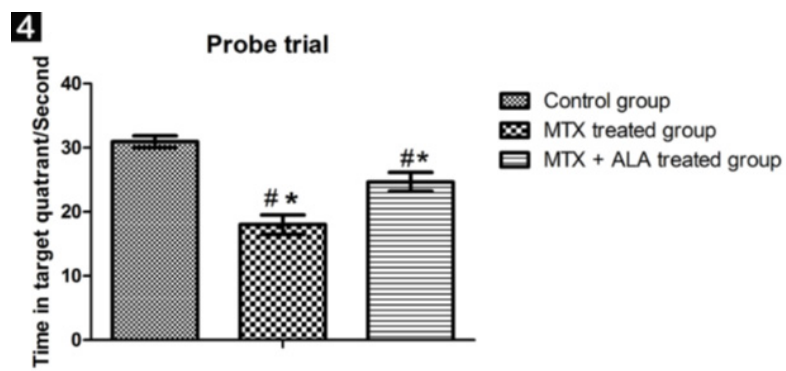

Fig. 4: Bar chart showing the time tnat tne rats spent in tne target quaarant. Lurıng re-traınıng on the fifth day post treatment, MTX rats spent significantly less time in the target quadrant compared with the control animals. Otherwise, MTX +ALA rats spent significantly more time in the target quadrant compared with the MTX rats but still revealing significant difference than the control rats. Statistical analysis was performed using one-way ANOVA, followed by Tukey's post hoc test. Values are represented as the mean \pm SE $(n=6)$. \# Significant difference compared to the control group, $P<0.05$. $*$ Significant difference compared to the MTX group, $\mathrm{P}<0.05$.

\section{5}

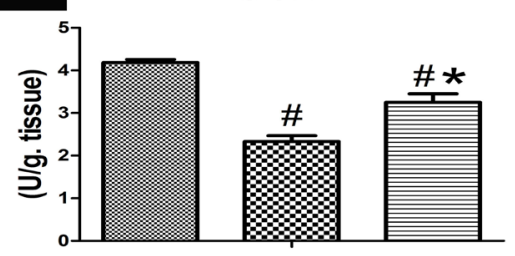

a

GSH

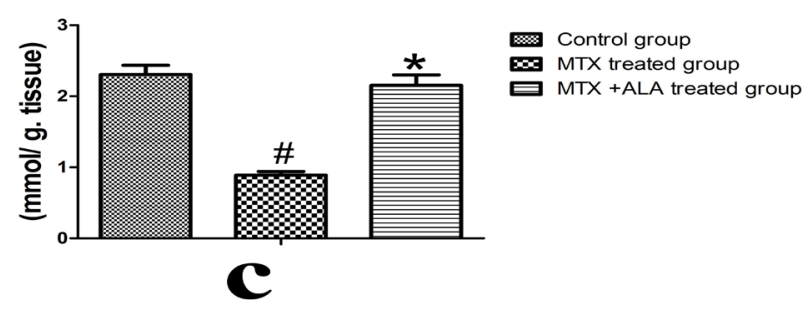

CAT

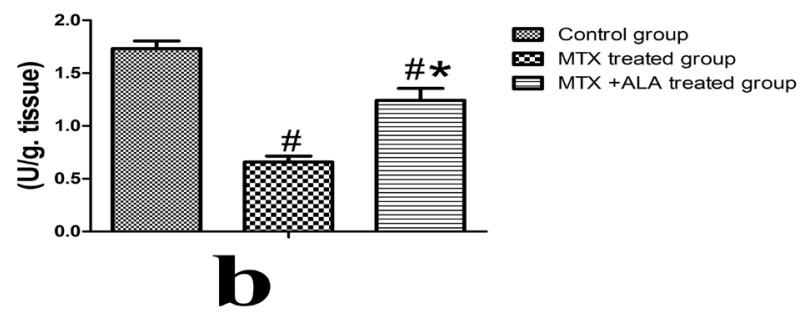

MDA

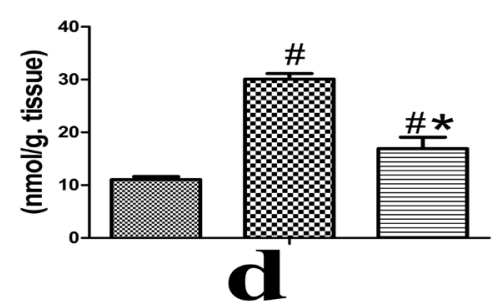

Control group

MTX treated group

Fig. 5: Bar charts showing the changes in the activities of a) SOD, b) CAT ,c) GSH and d) MDA in control, MTX treated group and MTX +ALA treated groups. Statistical analysis was performed using one-way ANOVA, followed by Tukey's post hoc test. Values are represented as the mean $\pm \mathrm{SE}(\mathrm{n}=6)$. \# Significant difference compared to the control group, $\mathrm{P}<0.05$. ${ }^{*}$ Significant difference compared to the MTX group, $\mathrm{P}<0.05$. 


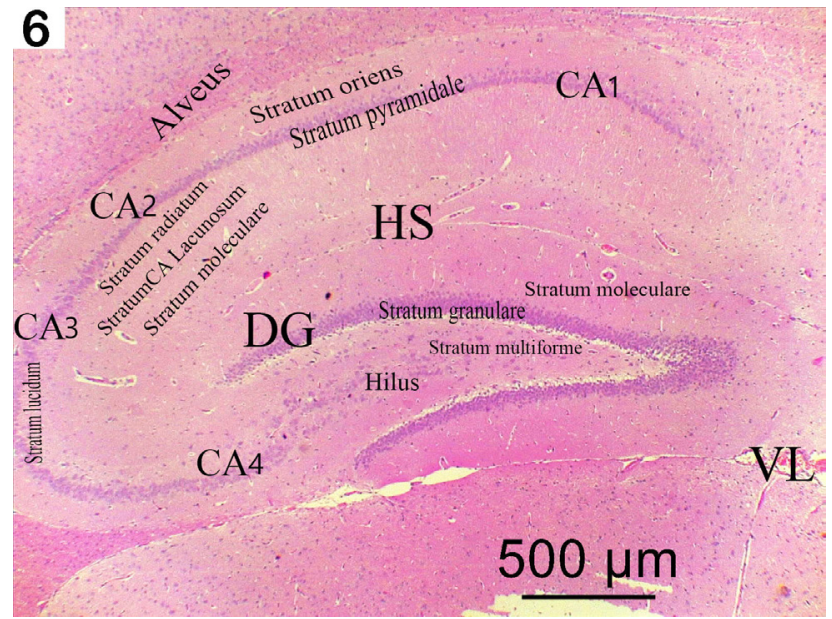

Fig. 6: A photomicrograph of a parasagittal section of rat hippocampus of control group showing: Cornu Ammonis regions:CA1:Cornu Ammoni, CA2:Cornu Ammoni 2,CA3: CornuAmmoni 3,Stratum Lucidum,Stratumoriens, Stratum radiatum, Stratum Lacunose, Stratum molecular, DG: Dentate Gyrus,Stratumgranulare, Stratum multiform, Hilus, (VL) Lateral Ventricle, (HS) Hippocapus sulcus, Alveus. $\mathrm{H} \& \mathrm{E}$ x $500 \mu \mathrm{m}, \mathrm{x} 40$.

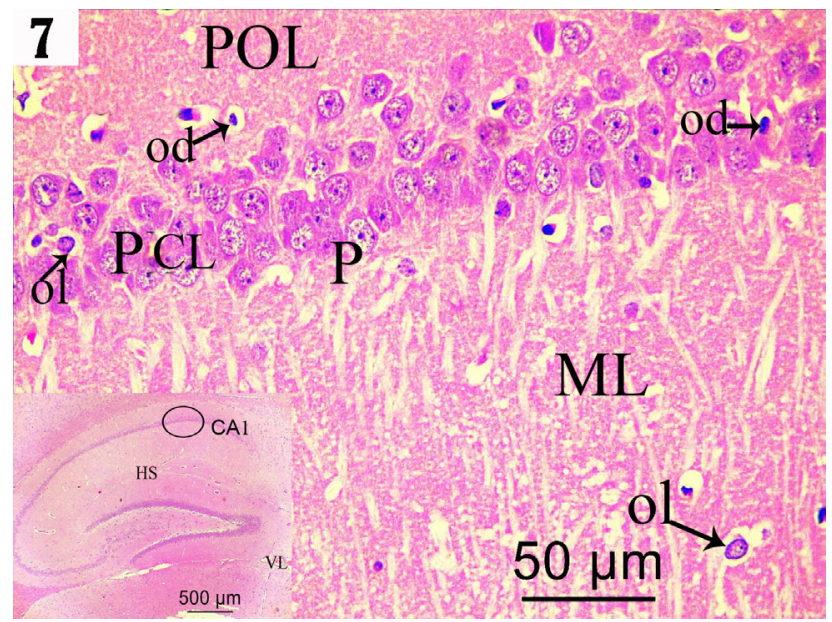

Fig. 7: A higher magnification of the circled area of (Fig.6) in the insult showing $\mathrm{CA} 1$ of control group with its three layers: Polymorphic layer (POL) containing deeply stained glialcells (Od), Pyramidal cell layer (PCL) containing pyramidal cells (P) with large rounded vesicular nucleus and prominent nucleoli. Glial cells with dark (od) or lightly (ol) stained nuclei can be seen. Molecular layer (ML) contains lightly stainedglial cells $\mathrm{H} \& \mathrm{E} x$ $50 \mu \mathrm{m}, \mathrm{x} 400$.

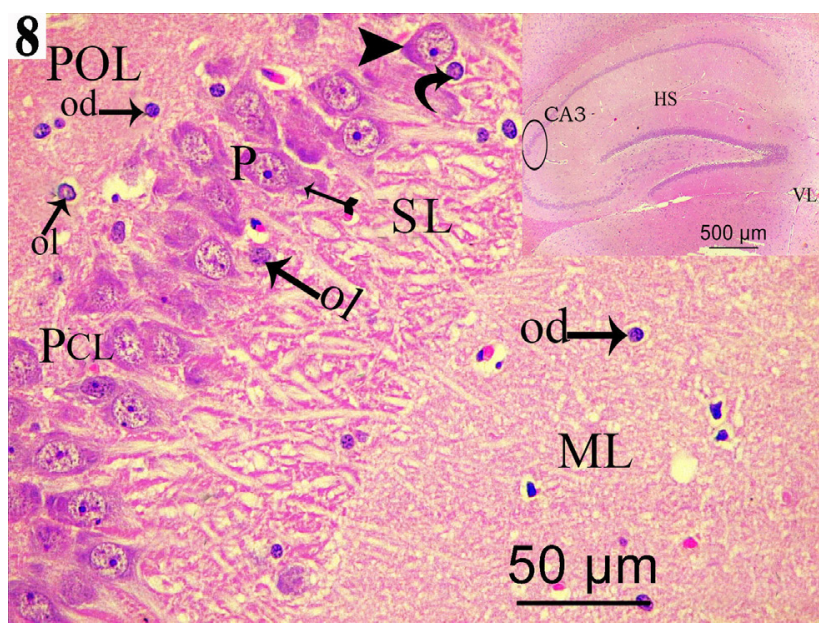

Fig. 8: A higher magnification of the circled area of (Fig.6) in the insult showing $\mathrm{CA} 3$ of control group with its three layers. Polymorphic layer (POL) containing eighter deeply stained (Od) or lightly stained (ol) glial cells. Septum lucidum layer (SL) can be observed. Pyramidal cell layer (PCL) containing pyramidal cells $(\mathrm{P})$ with large rounded vesicular nucleus and prominent nucleoli. Glial cells with lightly stained nuclei (ol) can be seen. Perineural glial cells can be observed (curved arrow). Note, apical dendrite(bifid arrow) and basal dendrite of pyramidal cells (head arrow). Molecular layer (ML) have glial cells with darkly stained nuclei and perinuclear halo (od). H\&E x $50 \mu \mathrm{m}$, x400.

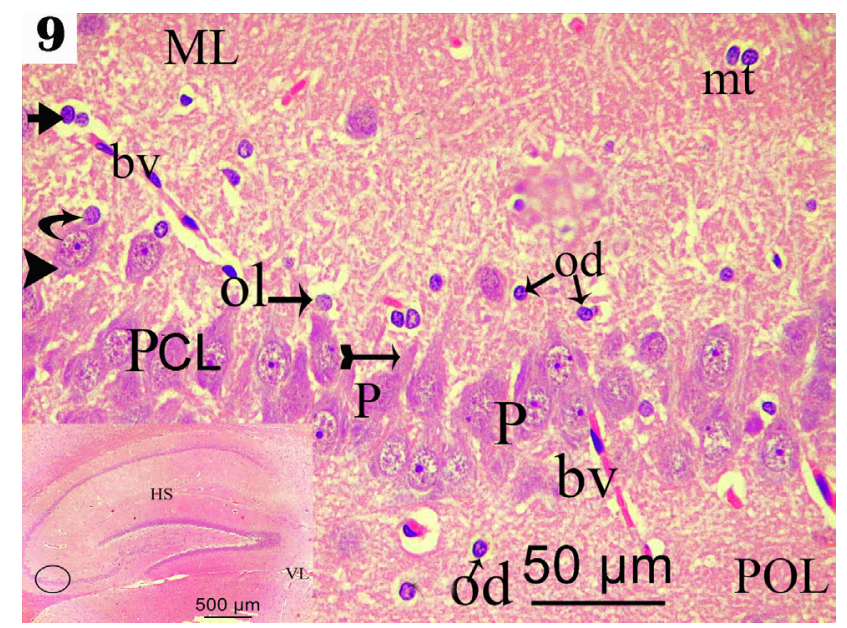

Fig. 9: A higher magnification of the circled area of (Fig.6) in the insult showing CA4 of control group with its three layers: Molecular layer (ML). Note probable glial mitotic cell division (mt) and blood vessel (bv) with perivascular glial cell (short arrow). Containing. Deeply stained glial cells (Od) can be observed.Pyramidal cell layer containing pyramidal cells (P) with large rounded vesicular nucleus and prominent nucleoli. Glial cells with lightly stained nuclei and perinuclear halo (ol). Blood vessels with narrow perivascular hallo can be observed. . Note, apical dendrite(bifid arrow) and basal dendrite of pyramidal cells (arrow head). Polymorphic layer (POL) containing deeply stained glial cells (Od). H\&E x $50 \mu \mathrm{m}$, x400. 


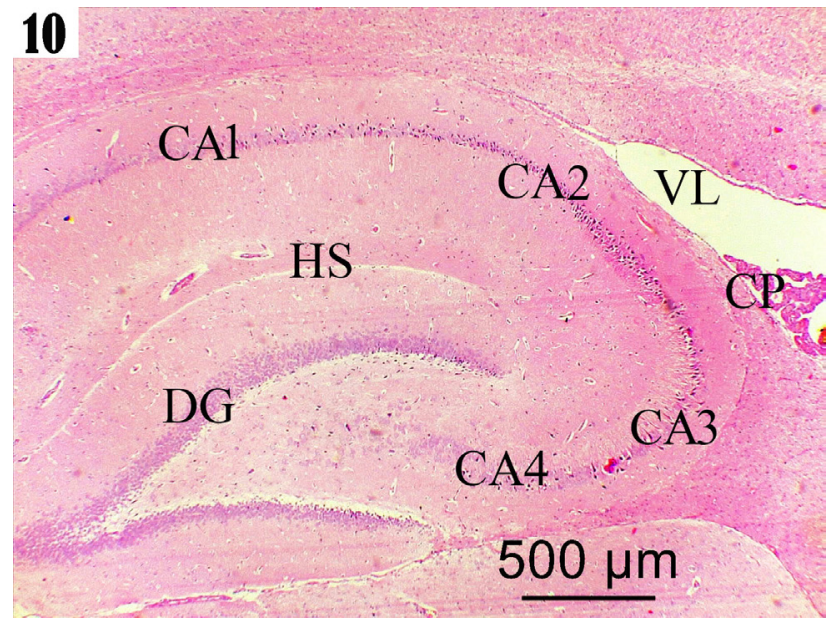

Fig. 10: A photomicrograph of a parasagittal section of rat hippocampus of MTX treated group showing: DG: Dentate Gyrus CA1: CornuAmmonis 1CA2: CornuAmmonis 2 CA3: CornuAmmonis $3 \mathrm{LV}$ : lateral ventricleHS: hippocampus sulcus ,CP: choroid plexus). H\&E x $500 \mu \mathrm{m}, \mathrm{x} 40$.

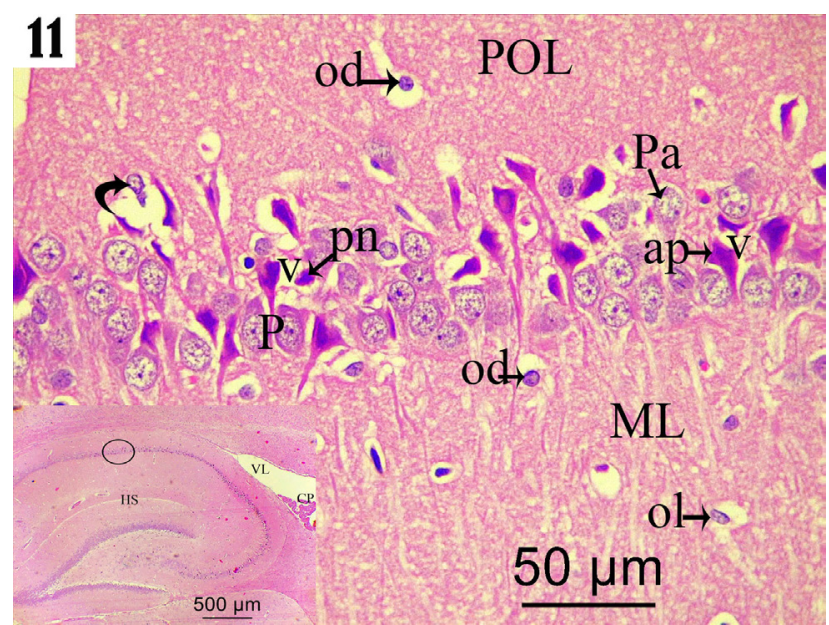

Fig. 11: A higher magnification of the circled area of (Fig.10) in the insult showing CA1 of MTX treated group with its three layers: POL have deeply stained (od) nuclei with widely pericellular space. PCL have dispersed cells (P) and some pyramidal cells having large lightly stained nuclei $(\mathrm{Pa})$.Others cells with shrunken deeply stained elongated nuclei (ap) with pericellular vaculation (v).Note pyknotic nuclei (pn) with pericellular vaculation (v). Perineural glail cells can be observed around the degenerated neurons (curved arrow). ML with either deeply stained (od) or lightly stained (ol) glail cells. H\&E x 50 $\mu \mathrm{m}, \mathrm{x} 400$.

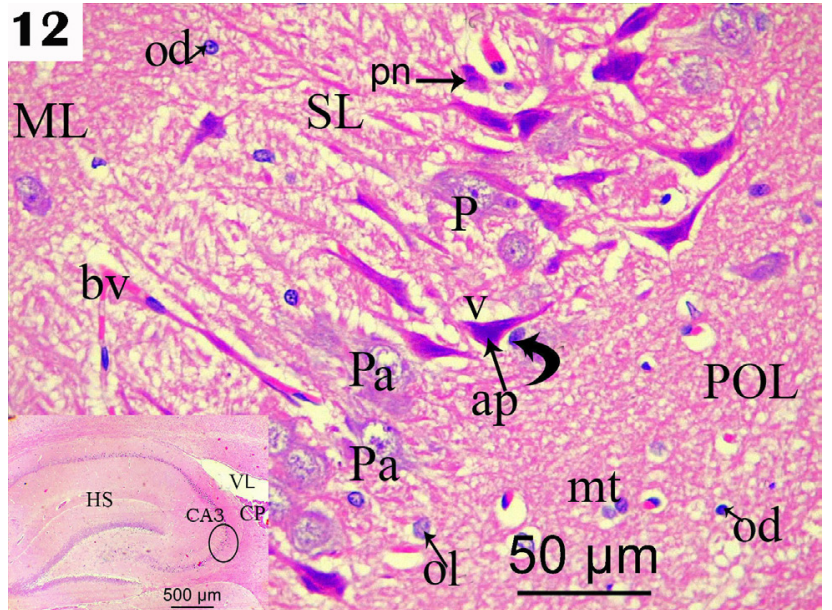

Fig. 12: A higher magnification of the circled areaof (Fig.10) in the insult of CA3 of MTX treated group showing its three layers: POL with deeply stained nuclei and mitotic cell dividing can be seen. Septum lucidum (SL) can be seen with blood vessels (bv). PCL showed the most cells of pyramidal cell layer with shrunken deeply stained elongatednuclei (ap) or pyknotic nuclei (pn) with pericellular vaculation (v). Few pyramidal cells having large lightly stained nuclei $(\mathrm{Pa})$ and few normal pyramidal cells can be seen $(\mathrm{P})$. Perineural oligodendrocytes can be observed (curved arrow). ML have deeply stained nuclei (od). H\&E x $50 \mu \mathrm{m}$, x 400 .

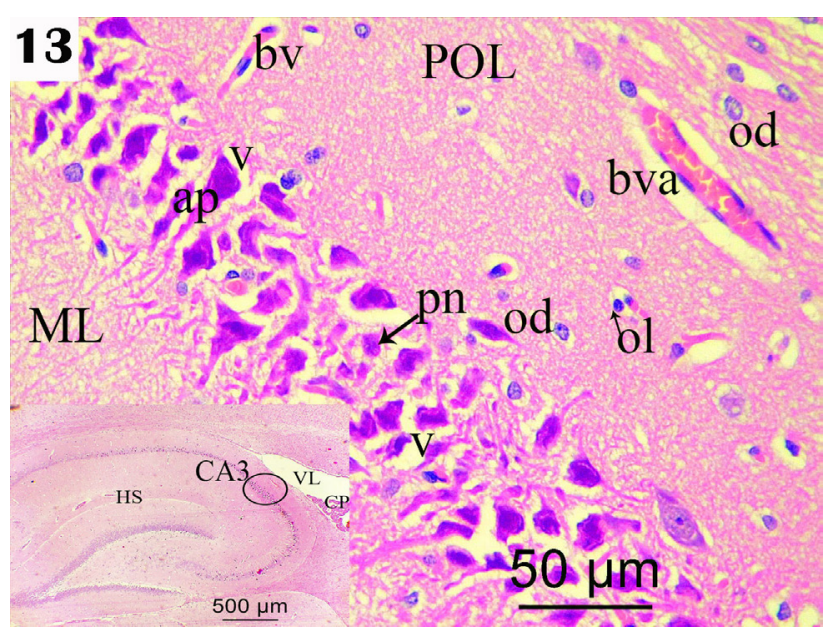

Fig. 13: Other higher magnification of the circled area of (Fig.10) in the insult of CA3 of MTX treated group showing most cells of PCL with shrunken deeply stained elongated nuclei (ap) or pyknotic nuclei (pn) with pericellular vaculation (v). POL had deeply (od) or lightlystained (ol) nuclei and congested dilated blood vessel (bva). H\&E x $50 \mu \mathrm{m}$, x 400 . 


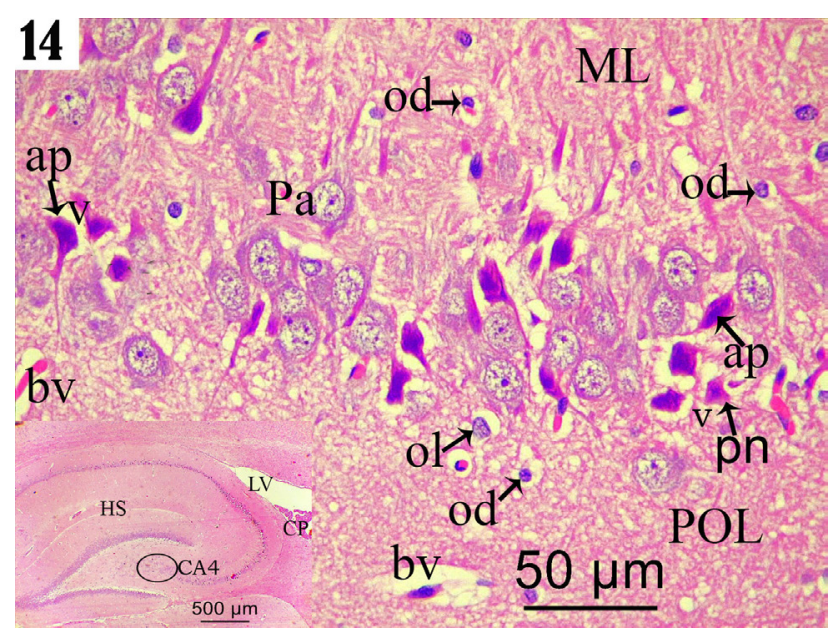

Fig. 14: A higher magnification of the circled areaof (Fig.10) in the insult showing CA4 of mtx treated group with its three layers: ML have deeply stained glail cells.with wide pericellular space (od).PCL with some pyramidal cells have large lightly stained nuclei $(\mathrm{Pa})$ and other cells with shrunken deeply stained elongatednuclei (ap) or pyknoticnuclei (pn) with pericellular vaculation (v). POL have either deeply (od) or lightly (ol) stained nuclei with wide pericellular space. Blood vessel with perivascular halocan be seen (bv). H\&E x $50 \mu \mathrm{m}, \mathrm{x} 400$.

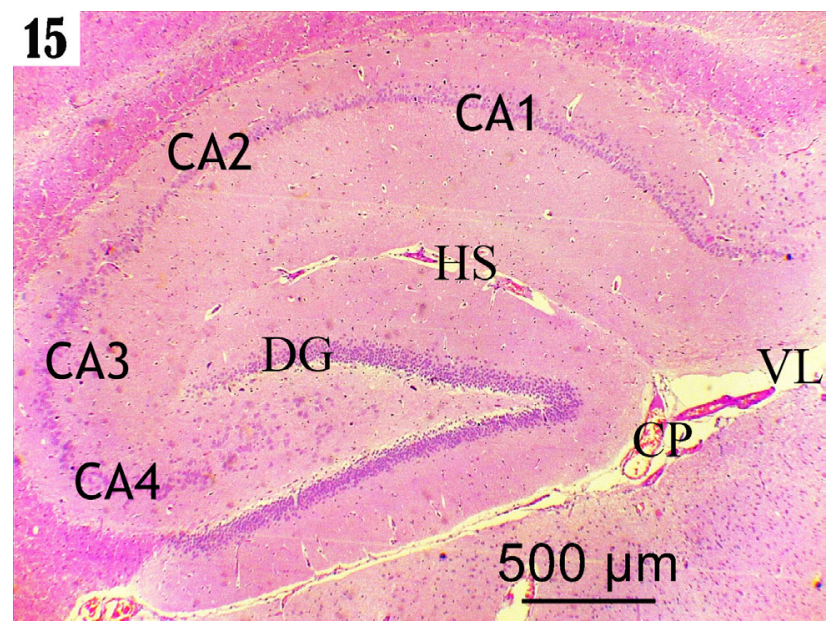

Fig. 15: A photomicrograph of a parasagittal section of rat hippocampus of MTX +ALA treated group showing: DG: Dentate Gyrus CA1: CornuAmmonis 1CA2: CoruAmmonis 2 CA3 CornuAmmonis $3 \mathrm{LV}$ : lateral ventricleHS: hippocampus sulcus ,CP: choroid plexus H\&E x $500 \mu \mathrm{m}$, x40

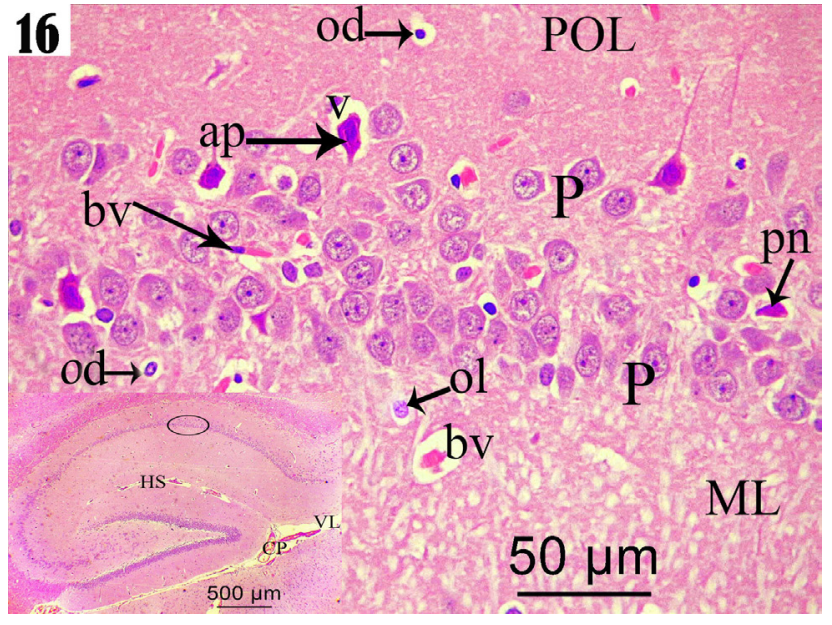

Fig. 16: A higher magnification of the circled areaof (Fig.15) in the insult showing CA1 with its three layers: POL have deeply stained nuclei and blood vessel (bv) with wide perivascular halo. PCL showing slightly dispersed neurons, which showed most pyramidal cells $(\mathrm{P})$ are normal and few degenerated cells with shrunken deeply stained elongated nuclei (ap) or pyknotic (Pn) nuclei with pericellula rvaculation (v) can be observed. Several blood vessel(bv) can also be noticed. ML with deeply stained. (od) and lightly stained(ol) glail cells nuclei H\&E x $50 \mu \mathrm{m}$, x 400 .

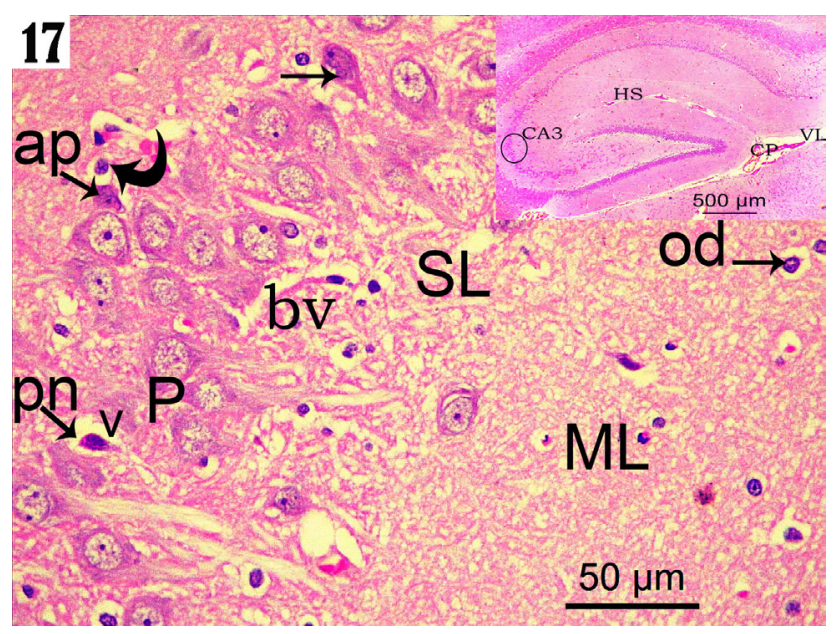

Fig. 17: A higher magnification of the circled area of (Fig.15) in the insult showing CA3 with its three layers: Molecular layer (ML) with deeply (od) stained nuclei with wide pericellular space. Pyramidal cell layer revealed most pyramidal cells $(\mathrm{P})$ are normal but with lightly stained cytoplasm and few are degenerated cells(ap) with Perineural glail cells.(curved arrow). or pyknotic nuclei (pn)with pericellular vaculation (v). Septum lucidum (SL) with blood vessel (bv) can be observed. Polymorphic layer (POL) $\mathrm{H} \& \mathrm{E}$ x $50 \mu \mathrm{m}, \mathrm{x} 400$. 


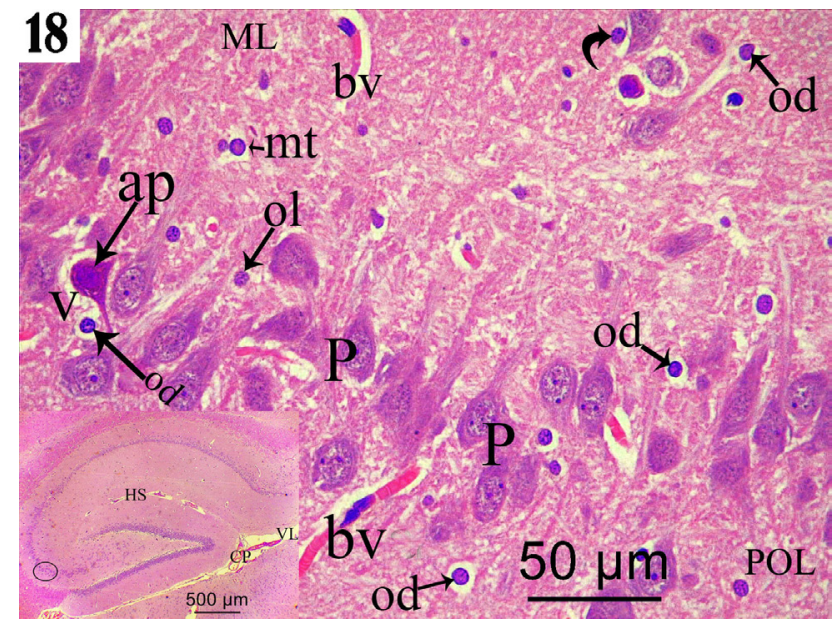

Fig. 18: A higher magnification of the circled area of (Fig.15) in the insult showing CA3 with its three layers: ML have glail cells. with deeply stained nuclei (od) and perineural glail cells.(curved arrow). Mitotic cell dividing (mt) and blood vessel (bv) can be seen in this layer. PCL containing mostly normal pyramidal cells (P) and few pyramidal cells with shrunken apoptotic deeply stained nuclei (ap)with pericellular vaculation (v). glail cells. with either deeply (Od) or lightly (ol) stained nuclei can be observed. POL with deeply stained nuclei (od) and blood vessel (bv) can be seen. H\&E x $50 \mu \mathrm{m}$, x 400 .

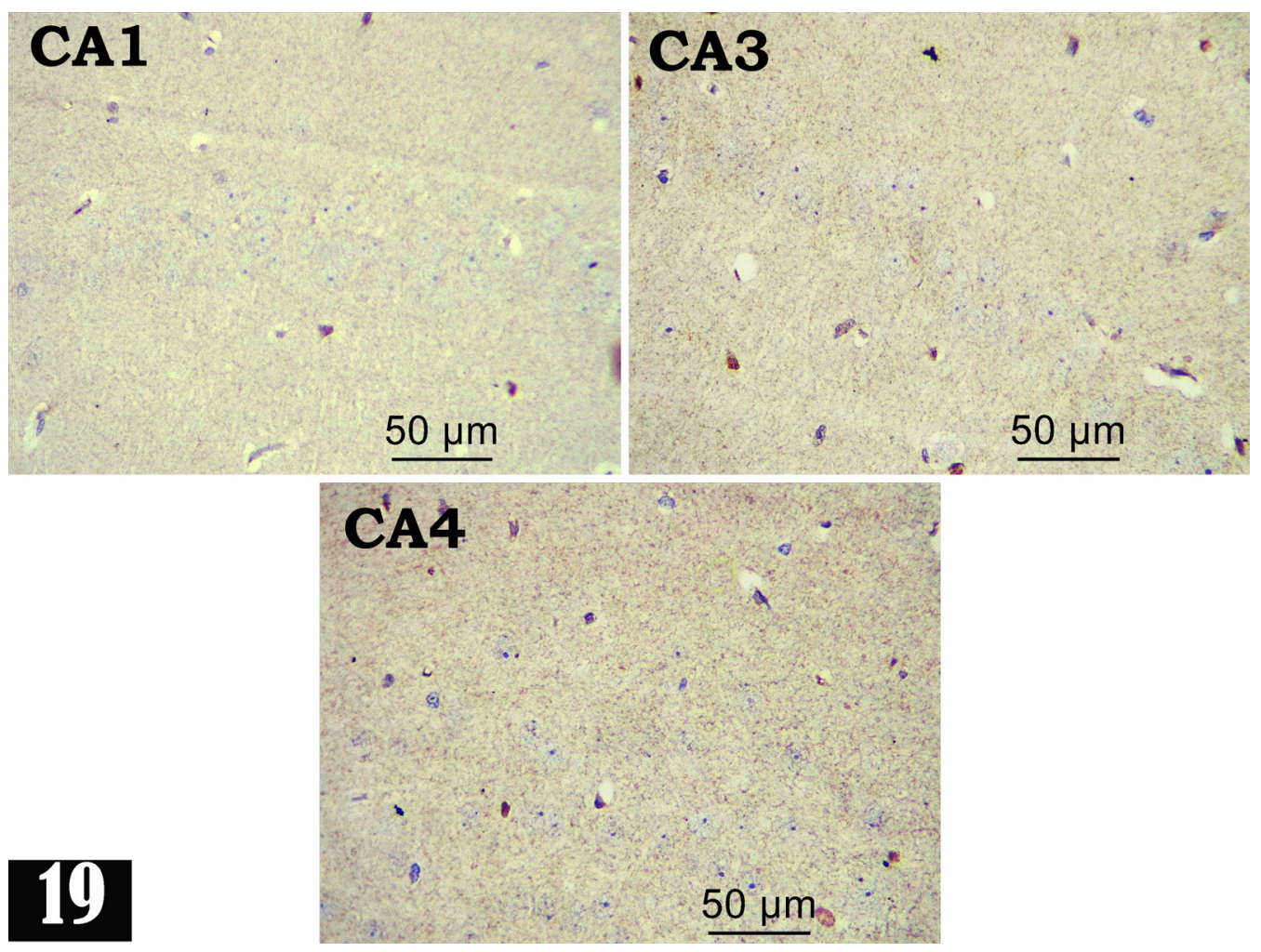

Fig. 19: A Photomicrograph of sections in different areas of hippocampus (CA1,Ca2,CA4) in control group showing negative immunoreactions to caspase -3. Immunoperioxidase technique for caspase-3, x $50 \mu \mathrm{m}, \mathrm{x} 400$. 


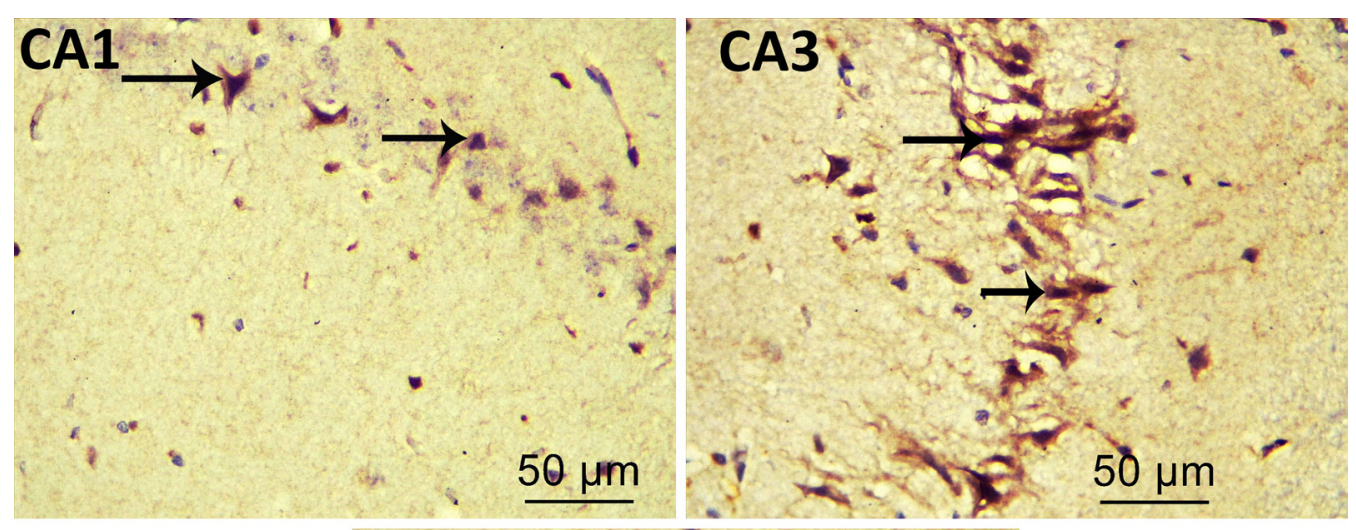

\section{0}

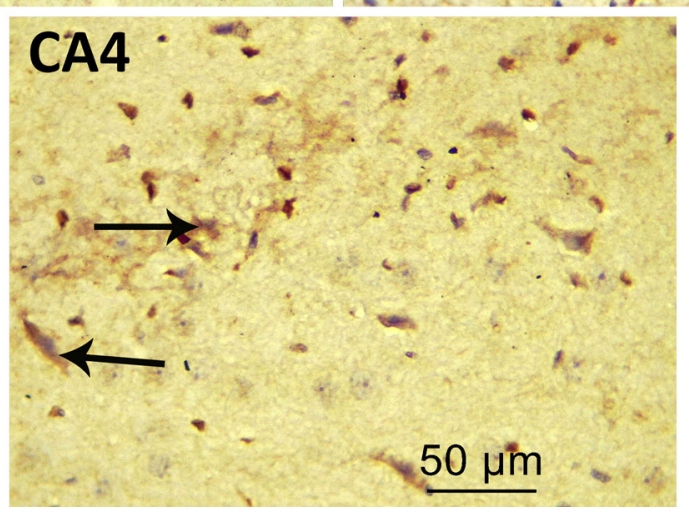

Fig. 20: A Photomicrograph of sections in different areas of hippocampus (CA1,Ca2,CA4) in MTX treated group showing numerous nerve cells having positive immunoreactions to caspase -3 in their cytoplasm (arrow) (especially in CA3) Immunoperioxidase technique for caspase-3, x $50 \mu \mathrm{m}, \mathrm{x} 400$.

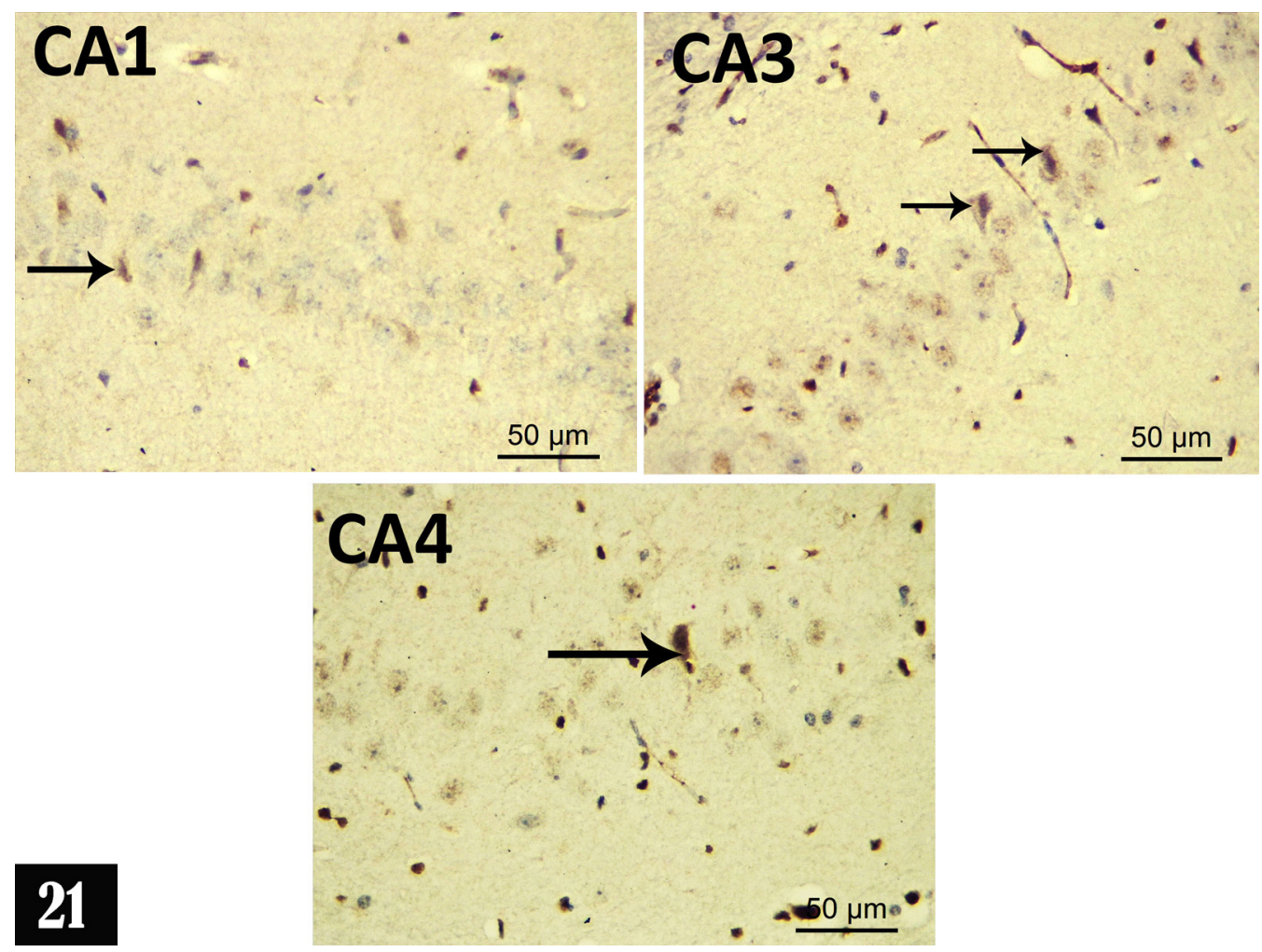

Fig. 21: A Photomicrograph of sections in the different areas of hippocampus (CA1,Ca2,CA4 ) in MTX + ALA treated group showing few nerve cells have positive immunoreactions to caspase -3 (arrow). Immunoperioxidase technique for caspase- 3 , x $50 \mu \mathrm{m}, \mathrm{x} 400$. 

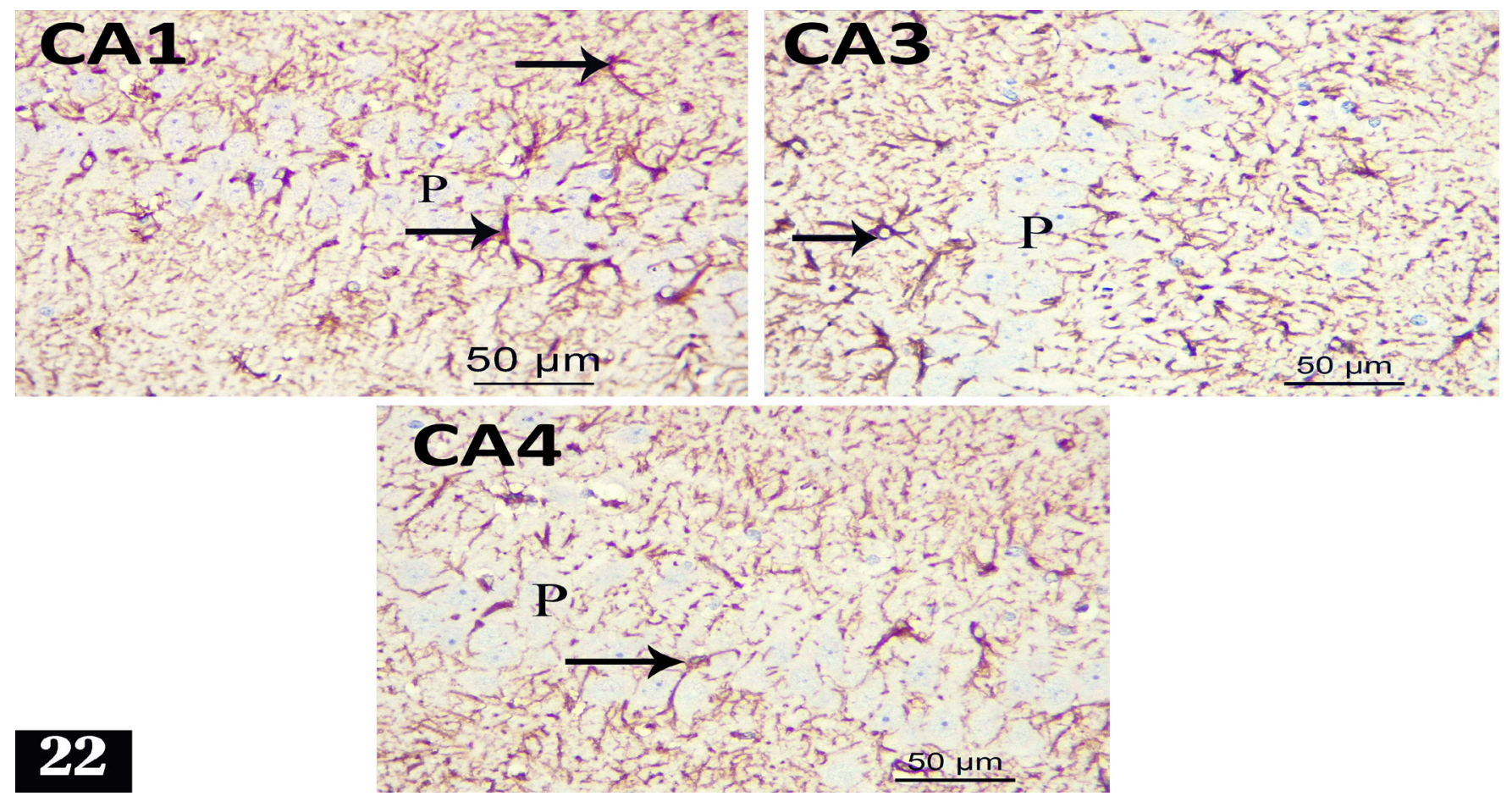

Fig. 22: A photomicrograph of immunohistochemical staining of GFAP in control group showing astrocytes with thin ramified processes inbetween the pyramidal cells (P) in CA1,CA3,CA4 regions.Many of astrocytes are seen dispersed among the molecular layer and polymorphic layers. Immunoperioxidase technique for GFAP, x $50 \mu \mathrm{m}, \mathrm{x} 400$.

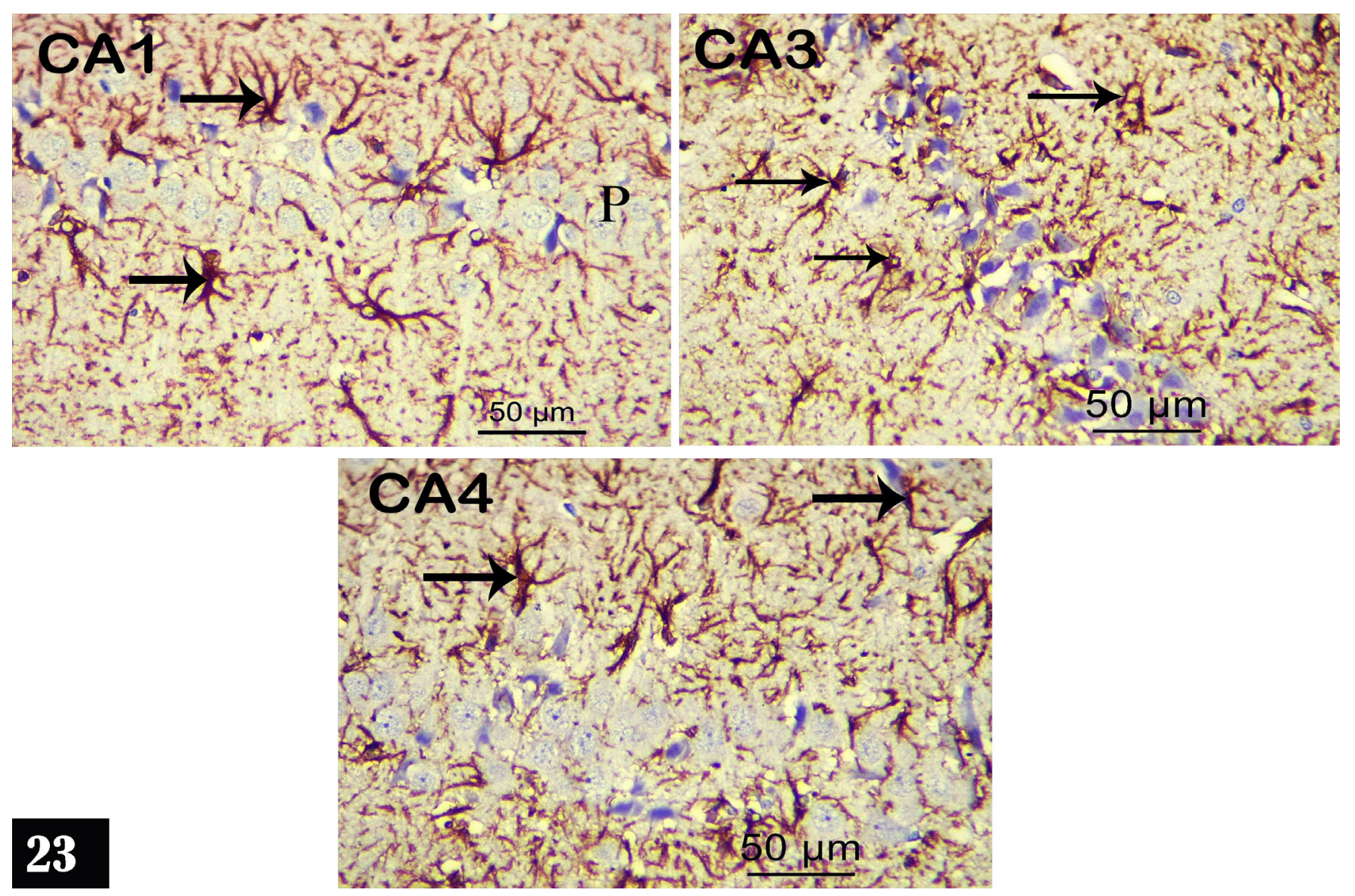

Fig. 23: A photomicrograph of immunohistochemical staining of GFAP in MTX treated group showing astrocytes with large ,multiple thick long processes (arrow). with thin ramified processes in-between the pyramidal cells (P) in CA1,CA3,CA4 regions.Many of astrocytes are seen dispersed among the molecular layer and polymorphic layers. Immunoperioxidase technique for GFAP, x $50 \mu \mathrm{m}, \mathrm{x} 400$. 

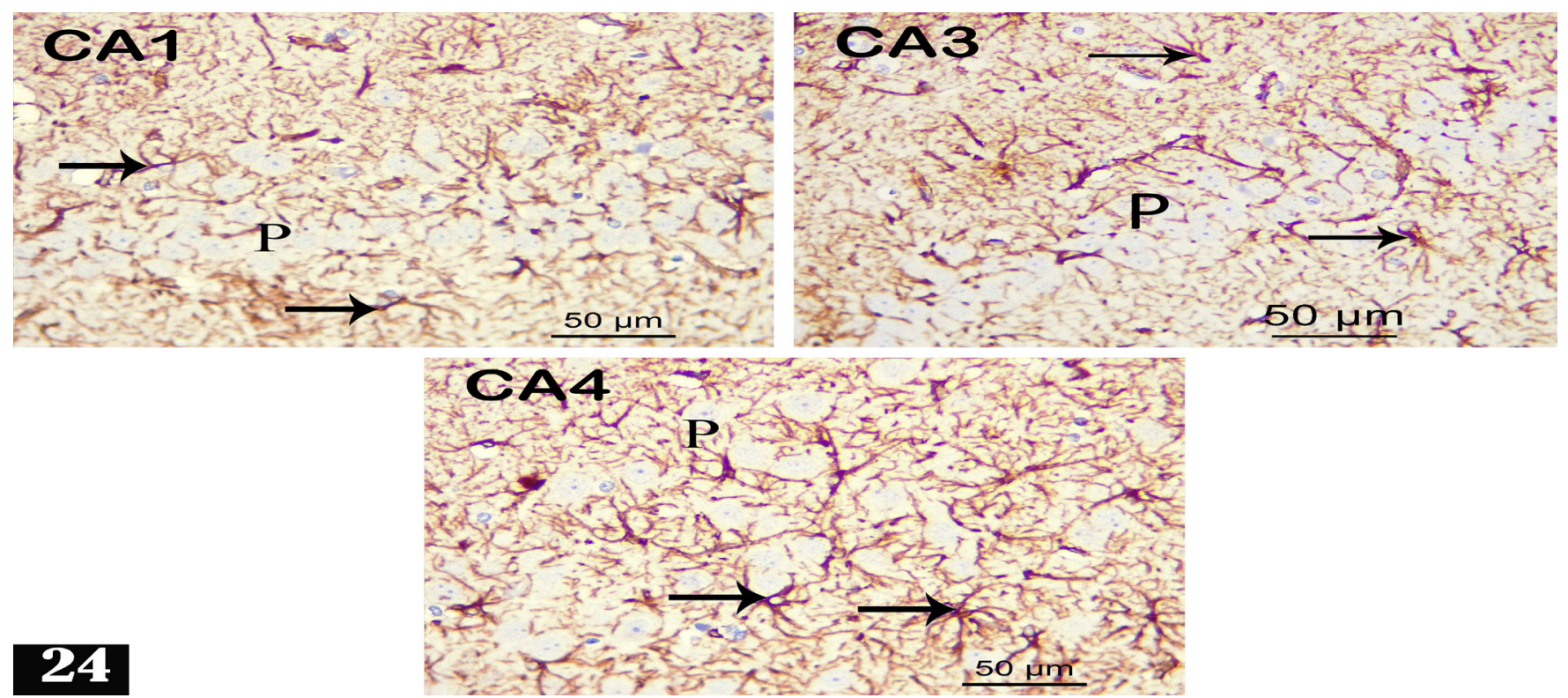

\section{4}

Fig. 24: photomicrograph of immunohistochemical staining of GFAP in MTX+ALA treated group showing astrocytes with large ,multiple thin long processes (arrow).with thin ramified processes in-between the pyramidal cells (P) in CA1,CA3,CA4 regions...Many of astrocytes are seen dispersed among the molecular and polymorphic layers. Immunoperioxidase technique for GFAP, x $50 \mu \mathrm{m}, \mathrm{x} 400$.

25

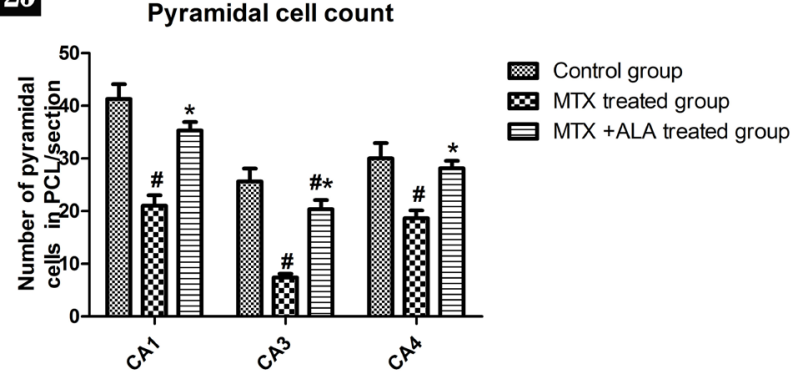

Fig. 25: Bar chart showing the comparison of the mean pyramidal cell count among thedifferent experimental groups(control, MTX and MTX +ALA treated groups) in the different areas of CornuAmmonis. Statistical analysis was carried out using one-way ANOVA, followed by Tukey's post hoc test. Values are represented as the mean $\pm S E(n=6)$. \# Significant difference compared to the control group, $\mathrm{P}<0.05$. $*$ Significant difference compared to the MTX treatedgroup , $\mathrm{P}<0.05$

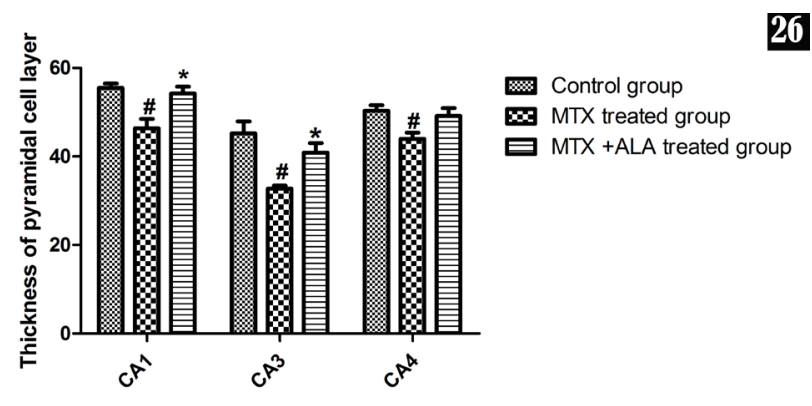

Fig. 26: Bar chart showing the comparison of the mean thickness of pyramidal cell layer among thedifferent experimental groups, Control, MTX and MTX +ALA treated groups in the different areas of CornuAmmonis. Statistical analysis was carried out using one-way ANOVA, followed by Tukey's post hoc test. Values are represented as the mean $\pm S E(n=6)$. \# Significant difference compared to the control group, $\mathrm{P}<0.05$. ${ }^{*}$ Significant difference compared to the MTX treated group , $\mathrm{P}<0.05$

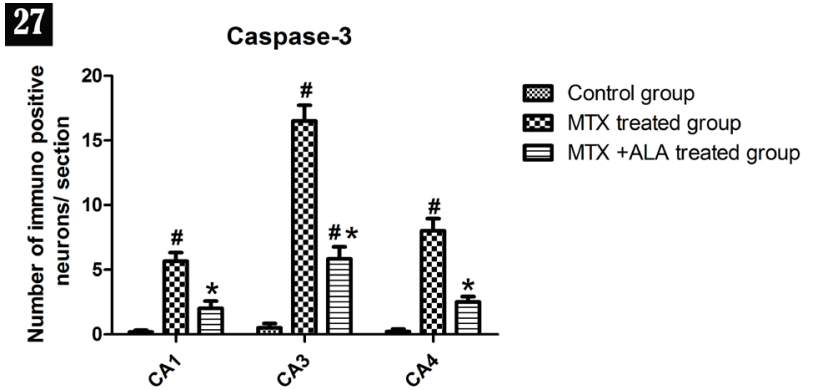

Fig. 27: Bar chart demonstrating the quantitative analysis of the number of caspase-3 immunopositive neurons in CA1,CA3, CA4 of the different experimental groups(Control, MTX and MTX +ALA treated groups). Statistical analysis was carried out using one-way ANOVA, followed by Tukey'spost hoc test. Values are represented as the mean $\pm \operatorname{SE}(n=6)$. \# Significant difference compared to the control group, $\mathrm{P}<0.05$. ${ }^{*}$ Significant difference compared to the MTX treated group , $\mathrm{P}<0.05$.

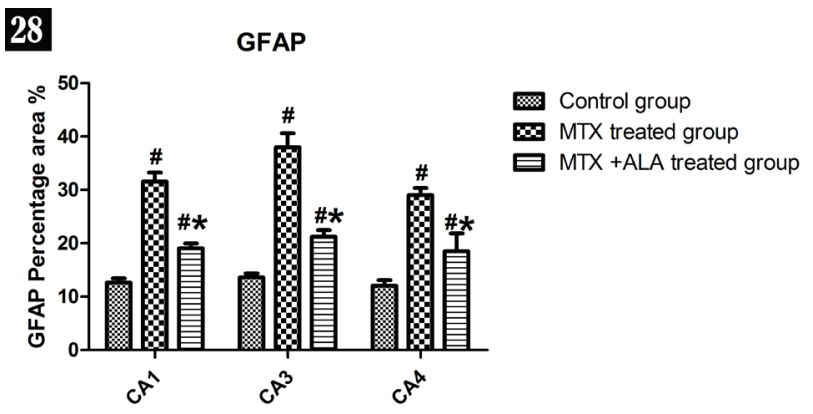

Fig. 28: Bar chart demonstrating the Area \% of GFAP positive astrocyte in CA1,CA3, CA4 of the different experimental groups(Control, MTX and MTX +ALA treated groups). Statistical analysis was carried out using one-way ANOVA, followed by Tukey'spost hoc test. Values are represented as The mean $\pm \operatorname{SE}(n=6)$. \# Significant difference compared to the control group, $\mathrm{P}<0.05$.*Significant difference compared to the MTX treatedgroup , $\mathrm{P}<0.05$. 


\section{DISCUSSION}

Methotrexate (MTX) belongs to the anti metabolite group, which is an anti neoplastic group of drugs. MTX has a wide range of therapeutic effects: e.g., at high doses in many malignancies and at low doses in autoimmune diseases such as rheumatoid arthritis and psoriasis, due to its anti- inflammatory and immunosuppressive effects ${ }^{[23]}$.

In the present work, the male albino rats was used to exclude the effect of female hormone. Estrogen hormones is proposed to enhance cell proliferation ${ }^{[35]}$.

The current work provided a clear evidence of a harmful effect of MTX on the hippocampus neurons in male albino rats in the form of histological, immune-histochemical changes and behavioural changes. Also this work assessed the antioxidant and the antiapoptotic properties of ALA on hippocampus tissue.

Rats treated with MTX exhibited low food consumption feeding with mild diarrhoea and weight loss during the 1st week of the experiment. Two rats died in the MTX-treated group on the $6^{\text {th }}$ day of administration. In the $2^{\text {nd }}$ week, all animals started to regain the body weight but still revealed significant difference from the control group. These results were consistent with other Seigers et al. ${ }^{[18]}$ who reported that all dosages of MTX used in study induced sickness approximately 3 days after treatment, as evidenced by decreased body weight, fluffy fur, bad general appearance and mild diarrhoea. After day 4, all animals recovered and started to regain body weight. These effects are similar to those observed in the patients treated with MTX also suffer from body weight loss and diarrhoea ${ }^{[36]}$.

To evaluate the effects of MTX on memory and learning capability in rats, we performed the widely used MWM test in this study. In this test, we noticed that MTX-treated rats spent more timetrying to find the hidden platform location (exhibited significantly greater escape latency than control rats. Additionally, MTX rats spent less time than control rats did in the target quadrantin the probe trial. Therefore, we conclude that MTX impairs spatial learning and recognition memory. These results are in accordance with those of ${ }^{[25,37]}$.

It was stated by other studies that methotrexate induce cognitive disability in rats. Animals treated by MTX didn't sufficiently learn a cognitive task, as appeared in a Morris test and a novel object recognition test. Furthermore, methotrexate also impaired the ability to consolidate a past learned undertaking, when treatment was given after the learning period of a Morris test and contextual fear conditioning ${ }^{[18]}$.

So several previous study on cognitive impairment because chemotherapy managment have been found to be related with hippocampal dysfunction. Hippocampus part of the limbic system and related to affective, cognitive, social and behavioral functions.
The results of the current histopathological study on the effects of MTX on the hippocampus showed both quantitative and qualitative changes in the CA1, CA4 and, to a greater extent in CA3. The hippocampal CA1 and CA3 areas play important roles in initial learning and memory in $\operatorname{rats}^{[38]}$.

In the current work, H\&E staining clarified different degenerative changes of the pyramidal cells in hippocampi of rats treated with MTX. In CA areas especially CA3 most of the pyramidal cells had shrunken irregular deeply stained nuclei, faint lightly stained nuclei or small pyknotic nuclei, this was associated with vacuolated cytoplasm. These results were in accordance with the $\mathrm{Wu}$, et $a l^{[25]}$. who reported that the pyramidal neurons revealed densely stained, and distorted cells with pyknotic appearance in MTX60, MTX100 and MTX250 groups.

Moreover, the current study showed that the MTX treated group had lightly stained pyramidal cells in their hippocampus. This may be clarified by Kaufmann et al ${ }^{[39]}$. who stated that the normal neurons were described have Nissl bodies composed of rough endoplasmic reticulum (rER) amalgamated with polyribosomes but the injured neurons, the Nissl bodies uder went partial or complete dissolution.

In addition to the above features, oligodendrocytes were noticed in close relative to some degenerated pyramidal cells. Clusters of oligodendrocytes near degenerating neuron cell bodies were described by Kaufmann et al ${ }^{[39]}$ to be a support for the neighboring neurons. This fact is a reaction to primary neuronal deterioration ${ }^{[40]}$.

The current study revealed a significant decrease in pyramidal cell count and pyramidal cell layer thickness of CA region especially CA3 in MTX treated group compared to the control group.

In correlation to the results of our study, the pyknosis further confirmed by caspase 3 immunohistochemical stain for apoptosis. The major result of the current study is that MTX treatment significantly increased the number of degenerated neuronal cells represented by increased of the caspase- 3 immuno positive neurons.Statistically, there was a significant increase in apoptotic cells in the CA1, CA4 region and a highly significant increase in CA3 of MTX treated group compared to those in the control group.

These resuts in consistent with Madhyastha et al., ${ }^{[41]}$ studies which discovered the number of neurons decreased in the CA3, CA4 of the hippocampus after intra thecal injection of MTX in rats. Also Seigers et al., ${ }^{[17]}$. stated that the animals treated with MTX showed a decrease in hippocampal cell proliferation.

Additionally, the hippocampal cell apoptosis was reported increased as the dose of MTX increased. Also indicated that MTX-related cognitive deficits may be associated with the apoptosis of hippocampus neurons ${ }^{[39]}$ 
stated that decreasing the neuronal cellularity usually follows necrosis or apoptosis of neurons and indicates the neuronal cell loss.

Immunohistochemical localization of GFAP was performed to inspect the allocation of astrocytes and their response to neuronal degeneration or injury ${ }^{[34]}$.

The current study revealed a bundant GFAP positive staining of the cytoplasm and processes of astrocytes. Astrocytes were apparently increased in number and appeared larger with multiple long thick processes in both pyramidal cells in CA region and also in molecular layers of rat hippocampi treated with MTX. There were significant increase in the area percent of GFAP in the MTX treated rats compared to control rats. Various studies have revealed the complex responses of astrocytes to injury. Increased protein content and immunostaining of GFAP have been established in experimental studies following gliosis ${ }^{[2]}$.

Moreover, astrocyte populations increase in or near damaged CNS regions during tissue repair (forming scars). Activated astrocytes may be evident neardamaged neurons, filling the sites where neuronal perikarya are absent and neuronal debris has been eliminated ${ }^{[39]}$.

For explain the previous histopathological findings and the behavior changes, the neurotoxic effect of MTX occur through oxidative stress and damage which is an imbalance between oxidants and antioxidants. The cells have developed antioxidant systems to counter the prooxidant fluxes. Among these antioxidant mechanisms are enzymes such as superoxide dismutase (SOD), catalase (CAT), glutathione peroxidase (GPX) and reduced glutathione (GSH). These enzymes react directly with the oxidizing radicals to yield non-radical agents. When the balance between ROS production and antioxidant defenses are changed, "oxidative stress" results, which through a series of events deteriorate the cellular functions and could possibly lead to various pathological conditions ${ }^{[43]}$.

Therefore, in our study, we assessed SOD, GSH, CAT and MDA activity. The results demonstrated that the SOD, GSH and CAT values were significantly lower in the MTX-treated group than in the control group. In contrast, the MDA values were significantly higher in the MTXtreated group than in the control group.

These results were in accordance with the studies of (Coleshowers et al., ${ }^{[44]}$ which showed a progressive decrease in SOD activity after the three weeks of MTX administration and this decrease could possibly be attributed to feedback inhibition or oxidative inactivation of enzyme proteins due to an excess of reactive oxygen species (ROS) generation ${ }^{[45]}$.

Additionally, other studies found that CAT activity increased during the first 2 weeks of MTX administration but decreased significantly upon continuous administration compared to control levels,. This suggesting that peroxidative damage to tissues probably commenced after 2 weeks of MTX administration Coleshowers et al. ${ }^{[45]}$.
These findings were also similar to other study that stated that the tissue GSH levels in the MTX group were lower than those in the control group ${ }^{[46]}$.

MTX-induced toxicity activates an inflammatory response and significantly increases the production of pro-inflammatory cytokines. Lipid peroxidation by free oxygen radicals is an important cause of oxidative damage to cell membranes ${ }^{[47]}$.

MDA is a highly biologically active product of the oxidative degradation of membrane unsaturated fatty acids. Thus, MDA is a reliable biomarker of lipid peroxidation ${ }^{[48]}$.

As stated by Kisaoglu et al. ${ }^{[49]} \mathrm{MDA}$ is an oxidant, while GSH is an antioxidant. Therefore, increased MDA and decreased GSH levels indicate the development of oxidative stress.

Studies had shown that oxidative stress can activate mitochondrial apoptotic pathways. Seizures increase ROS formation and induce mitochondrial oxidative damage leading to mitochondrial dysfunction and enhanced permeability with consequent release of mitochondrial cytochrome c leading to apoptosis ${ }^{[50,51]}$. Furthermore, apoptosis related proteins including Bax, Bcl-2 family and caspase- 3 can regulate plastic changes of neurotransmission independent of acute cell death in the CNS and may play a significant role in epileptogenesis ${ }^{[52,53,54]}$.

These results were in consistent with Ahles and Saykinet ${ }^{[55]}$ who described several potential mechanisms for this cognitive impairment induced by MTX, which could also contribute to the decrease in cell proliferation; these mechanisms include DNA damage, oxidative stress, encephalopathy, cytokine activation. Other studies had shown that oxidative stress can activate mitochondrial apoptotic pathways ${ }^{[50,51]}$.

ALA plays a unique antioxidant role in the CNS because it has the ability to cross the blood-brain barrier, and it is taken up equally by the CNS and the peripheral nervous system due to both hydrophilic and lipophilic properties; thus, it can be absorbed and distributed easily into all body tissues $^{[56,57,58]}$. Furthermore, ALA is a powerful antioxidant and neuroprotective agent that naturally occurs in the body and is also present in some foods ${ }^{[59,60]}$. There were also some studies on the effect ALA on peripheral nervous system disorders. It was reported that ALA had a protective effect on mitochondrial damage and on neurotoxicity caused by chemotherapeutic agents ${ }^{[61]}$.

In this study, co-administration of ALA with MTX improved cognitive function. In the MWM test, we noticed that MTX +ALA-treated rats spent less time trying to find the hidden platform (exhibited a significantly lower escape latency) than MTX-treated rats. Additionally, MTX rats spent less time in the target quadran tin the probe trial than the MTX-treated rats. But still revealed a significant difference from the control group.

These results are in accordance with other studies which found that administration of ALA ameliorated cholinergic 
deficiency and improved spatial learning and memory performance in the MWM. The authors speculated that these beneficial effects may have been related to changes in monoamine concentrations in the hippocampus ${ }^{[62,63]}$.

Additionally, it was demonstrated that ALA may improve learning and memory in the animal hippocampus and cerebral cortex of in numerous ways: (i) by affecting theneurotransmitter acetylcholine (Ach); (ii) by increasing glucose uptake (increasing ATP production); (iii) by inhibiting the formation of hydroxyl radicals; (iv) by scavenging ROS andthus downregulating inflammatory processes; (v) by scavenging lipid peroxidation products; and (vi) by inducing GsH synthesis enzymes ${ }^{[64]}$.

Additionally, it was concluded that ALA reverses cognitive dysfunction at least partly through its antioxidant properties $^{[63,65]}$.

In the current work, the degenerative histological changes observed in rats subjected to MTX treatment were markedly diminished in rats treated with ALA for 3 weeks started 3 days before MTX administration. The pyramidal cell structures were similar between the MTX+ALA group and the control group however, a few cells revealed vacuolation or cytoplasmic degeneration together with irregular or small, shrunken, pyknotic nuclei. Some neuronal processes retained their integrity. Additionally, GFAP expression (as the area percent of staining) was significant decreased in all hippocampal areas in the MTX+ALA group compared to the MTX-treated group.

The current study revealed significant increases in pyramidal cell count and PCL thickness in the CA region in the MTX + ALA-treated group compared to the MTXtreated group. ALA administration decreased apoptosis, as proven by the significantly fewer cells immune positive for caspase-3 in CA areas in MTX+ALA-treated rats than in MTX-treated rats. However,there was still a significant difference in the number of immunopositive cells in the CA3 area and non significant differences in the numbers of immunopositive cells in the CA1 and CA4 regions between the MTX+ALA group and the control group. These results are in agreement with a previous study in which it was reported $^{[66]}$ that one of the possible mechanisms of ALA's protective effect may be a decrease in apoptosis.

Additionally, it was found that ALA has a modulatory effect on apoptosis-associated proteins, as indicated by upregulation of $\mathrm{Bcl}-2$ and downregulation of Bax, suggesting a positive influence of ALA on cell survival and the capability of ALA to stimulate various neuroprotective and repair pathways ${ }^{[67]}$.

Several endogenous antioxidant enzymes such as SOD, is a very vital cellular antioxidant that keeps the cells from the free radicals. (CAT and GSH are examples of several endogenous antioxidant enzymes which can detoxify the reactive oxygen species. SOD and CAT are concerned with the elimination of superoxide anion and peroxide ${ }^{[68]}$. Their increase in tissue indicates an increase of antioxidant activity ${ }^{[69,70]}$.
The current study results regarding oxidative stress biomarkers supports those of previous studies on the protective role of ALA. Our results revealed significantly higher levels of the antioxidant enzymes CAT, SOD and GSH and significantly lower levels of MDA in the MTX+ALA group than in the MTX-treated group. Although the CAT,SOD and MDA levels in the MTX+ALA group were significant different from those in the control group but the GSH levels did not significantly differ from the control. These results are in accordance with those of Dixit et $a l^{[67]}$. who found that the ameliorative effects of ALA are associated with its role in neutralizing insult-stimulated ROS and preserving cortical and hippocampal GSH levels under compromised conditions, such as ischaemia and exposure to toxic insults. It has been suggested that ALA exerts its antioxidant effect primirly through GSH.

It was demonstrated that ALA significantly increases tissue SOD and GSH activity. In addition, ALA increases de novo synthesis of cellular GSH by improving cysteine utilization $^{[58,71]}$.

Also, ALA intake may reduce inflammatory markers by down-regulating pro-inflammatory redox-sensitive signal transduction processes including nuclear factor kappa B translocation, leading to lower release of other free radicals and cytotoxic cytokines ${ }^{[72]}$. All of these properties of ALA make it a powerful antioxidant agent suitable for both prevention and treatment in various disease.

Taken together, interpretation of our experimental results proved substantial antioxidant and anti-apoptotic ameliorative impacts of ALA on the hippocampal function, cyto-morphological and immunohistochemical effects induced by MTX. So we recommended ALA to be considered as a supplementation during MTX therapy

\section{ABBREVIATIONS}

MTX: Methotrexate, ALA: Alpha lipoic acid, MDA: Malondialdehyde.

\section{CONFLICTS OF INTERESTS}

There are no conflicts of interest.

\section{REFERENCE}

1. Aggleton JP (2012): Multiple anatomical systems embedded within the primate medial temporal lobe: Implications for hippocampal function. Neuroscience and Biobehavioral Reviews, 36 (7):1579-1596.

2. Morris, R. (2007). Theories of hippocampal function. Anderson P, Morris R, Amaral D, Bliss T, O'Keefe J, editors. The Hippocampus Book.

3. El Falougy, H., Kubikova, E., \& Benuska, J. (2008). The microscopical structure of the hippocampus in the rat. Bratislavske lekarske listy, 109(3), 106.

4. Boccara CN, Kjonigsen LJ, Hammer IM, Bjaalie JG, Leergaard TB and Witter MP (2015): A three-plane architectonic atlas of the rat hippocampal region. Hippocampus 25(7), 838-857. 
5. Shuper, A., Stark, B., Kornreich, L., Cohen, I. J., Aviner, S., Steinmetz, A., \& Yaniv, I. (2000). Methotrexate treatment protocols and the central nervous system: significant cure with significant neurotoxicity. Journal of child neurology, 15(9), 573-580.

6. Rajitha, P., Biswas, R., Sabitha, M., \& Jayakumar, R. (2017). Methotrexate in the treatment of psoriasis and rheumatoid arthritis: Mechanistic insights, current issues and novel delivery approaches. Current pharmaceutical design, 23(24), 3550-3566.

7. Buizer, A. I., de Sonneville, L. M., van den HeuvelEibrink, M. M., \& Veerman, A. J. (2006). Behavioral and educational limitations after chemotherapy for childhood acute lymphoblastic leukemia or Wilms tumor. Cancer: Interdisciplinary International Journal of the American Cancer Society, 106(9), 2067-2075.

8. Buizer AI, de Sonneville LM, van den HeuvelEibrink MM, Veerman AJ. 2005. Chemotherapy and attentional dysfunction in survivors of childhood acute lymphoblastic leukemia: effect of treatment intensity. Pediatr Blood Cancer; 45: 281-290.

9. Cole, P. D., \& Kamen, B. A. (2006). Delayed neurotoxicity associated with therapy for children with acute lymphoblastic leukemia. Mental retardation and developmental disabilities research reviews, 12(3), 174-183.

10. Buizer AI, de Sonneville LM, Veerman AJ.2009. Effects of chemotherapy on neurocognitive function in children with acute lymphoblastic leukemia: a critical review of the literature. Pediatr Blood Cancer; 52: 447-54.

11. Rollins, N., Winick, N., Bash, R., \& Booth, T. (2004). Acute methotrexate neurotoxicity: findings on diffusion-weighted imaging and correlation with clinical outcome. American Journal of Neuroradiology, 25(10), 1688-1695.

12. Abd El-Twab SM, Hozayen WG, Hussein OE, Mahmoud AM (2016): 18ß-Glycyrrhetinic acid protects against methotrexate-induced kidney injury by up-regulating the Nrf2/ARE/HO-1 pathway and endogenous antioxidants. Ren Fail;38(9):1516-1527.

13. Kolli, V. K., Natarajan, K., Isaac, B., Selvakumar, D., and Abraham, P. (2014). Mitochondrial dysfunction and respiratory chain defects in a rodent model of methotrexate-induced enteritis. Human and experimental toxicology, 33(10), 1051-1065.

14. Abd El-Twab SM, Hozayen WG, Hussein OE, Mahmoud AM (2016): 18ß-Glycyrrhetinic acid protects against methotrexate-induced kidney injury by up-regulating the Nrf2/ARE/HO-1 pathway and endogenous antioxidants. Ren Fail; 38(9):1516-1527.

15. Naik, S. R., and Panda, V. S. (2007).Antioxidant and hepatoprotective effects of Ginkgo biloba phytosomes in carbon tetrachloride-induced liver injury in rodents. Liver international, 27(3), 393-399.

16. Mahmoud AM and Abd El-Twab SM (2017): Caffeic acid phenethyl ester protects the brain against hexavalent chromium toxicity by enhancing endogenous antioxidants and modulating the JAK/STAT signaling pathway. Biomed Pharmacother; 91:303-311.

17. Seigers, R., Pourtau, L., Schagen, S.B., van Dam, F.S., Koolhaas, J.M., Konsman, J.P., Buwalda, B., 2010. Inhibition of hippocampal cell proliferation by methotrexate in rats is not potentiated by the presence of a tumor. Brain Research Bulletin 81, 472-476.

18. Seigers R, Schagen SB, Beerling W, Boogerd W, van Tellingen O, van Dam FS, Koolhaas JM, Buwalda B (2008): Long-lasting suppression of hippocampal cell proliferation and impaired cognitive performance by methotrexate in the rat. Behavioural brain research 186:168-175.

19. Maritim, A. C., Sanders, R. A., \& Watkins Iii, J. B. (2003).Effects of $\alpha$-lipoic acid on biomarkers of oxidative stress in streptozotocin-induced diabetic rats. The Journal of nutritional biochemistry, 14(5), 288-294.

20. Rochette L, Ghibu S, Richard C, Zeller M, Cottin Y and Vergely C (2013) : Direct and indirect antioxidant properties of $\alpha$-lipoic acid and therapeutic potential Molecular Nutrition \& FoodResearch. 57(1): 114-125.

21. Moini H, Packer L and Saris NE (2002): Antioxidant and prooxidantactivities of alpha - lipoic acidand dihydrolipoic acid. Toxicol Appl Pharmacol. 182(1):84-90.

22. Liu, J. (2008). The effects and mechanisms of mitochondrial nutrient $\alpha$-lipoic acid on improving ageassociated mitochondrial and cognitive dysfunction: an overview. Neurochemical research, 33(1), 194-203

23. Armagan I, Bayram D, Candan IA, Yigit A, Celik E, Armagan $\mathrm{HH}$ \&Uğuz AC (2015): Effects of pentoxifylline and alpha lipoic acid on methotrexate-induced damage in liver and kidney of rats. Environmental Toxicology and Pharmacology, 39(3), 1122-1131

24. Al Rasheed N, Abdel Baky N, Al Rasheed N, Shebly W, Ahmed A and Faddah A (2012): Effect of vitamin $\mathrm{E}$ and $\alpha$-lipoic acid on nano zinc oxide induced renal cytotoxicity in Rats African Journal of Pharmacy and Pharmacology August; 6(29): 2211-2223.

25. Wu LL, Lin DN, Yu LH \& Yang LH (2017): Endoplasmic reticulum stress plays an important role in methotrexate-related cognitive impairment in adult rats. international journal of clinical and experimental pathology, 10(10), 10252-10260. 
26. Vorhees CV, Williams MT (2014): Assessing spatial learning and memory in rodents. ILAR J. 55, 310-332.

27. Xing Y, Qin Y, Jing W, Zhang Y, Wang Y, Guo D, Xia Y, Yao D (2016): Exposure to Mozart music reduces cognitive impairment in pilocarpine-induced status epilepticus rats. Cogn.Neurodyn. 10, 23-30.

28. Kanjana K, Haygarth KS, Wu W \& Bartels DM (2013). Laboratory studies in search of the critical hydrogen concentration. Radiation Physics and Chemistry, $82,25-34$

29. Nishikimi M, Rao NA\& Yagi K (1972): The occurrence of superoxide anion in the reaction of reduced phenazine methosulfate and molecularoxygen. Biochemical and biophysical research communications,46(2), 849-854.

30. Aebi H (1984): Catalase in Vitro. Methods Enzymol. $105,121-126$

31. Ellman GL (1959): Tissue sulfhydryl groups. Arch. Biochem. Biophys. 82, 70-77

32. Bancroft, J. D., and Layton, C. The hematoxylin and eosin. Bancroft's Theory and Practice of Histological Techniques, Expert Consult: Online and Print, 2012; $7^{\text {th }}$ edn. p. 173, Elsevier: Amsterdam, Netherlands

33. Martin, P.M. andO'Callaghan, J.P. (1995): A direct comparison of GFAP immunocytochemistry and GFAP concentration in various regions of ethanol-fixed rat and mouse brain. Journal of Neuroscience Methods, 58(1-2): 181-192.

34. Chen H and Weber AJ (2002):Expression of glial fibrillary acidic protein and glutamine synthetase by müller cells after optic nerve damage and intravitreal application of brain derived neurotrophic factor. Glia, 38(2), 115-125

35. Tanapat P, Hastings NB, Reeves AJ, and Gould E (1999): Estrogen stimulates a transient increase in the number of new neurons in the dentate gyrus of the adult female rat. Journal of neuroscience. 15; 19(14): 5792-5801

36. Flombaum, C. D., \& Meyers, P. A. (1999). High-dose leucovorin as sole therapy for methotrexate toxicity. Journal of clinical oncology, 17(5), 1589-1589.

37. Yang, X., \& Li, L. (2011). miRDeep-P: a computational tool for analyzing the microRNA transcriptome in plants. Bioinformatics, 27(18), 2614-2615

38. Bahar AS, Shirvalkar PR \& Shapiro ML (2011):Memory-guided learning: CA1 and CA3 neuronal ensembles differentially encode the commonalities and differences between situations. Journal of Neuroscience, 31(34), 12270-12281.

39. Kaufmann W, Bolon B, Bradley A, Butt M, Czasch S, Garman RH, George C, Gröters S, Krinke G, Little P, McKay J, Narama I, Rao D, Shibutani Mand Sills
R (2012): Proliferative and Nonproliferative Lesions of the Rat and Mouse Central and Peripheral Nervous Systems. Toxicol.Pathol., 40: 87S.

40. Franklin, R. J. M. and Kotter, M. R. (2008): The biology of CNS remyelination. J. Neurol., 255: 19-25.

41. Madhyastha S, Somayaji SN, Rao MS, Nalini K and Bairy KL (2002): Hippocampal brain amines in methotrexate-induced learning and memorydeficit. Canadian journal of physiology and pharmacology, 80 (11), 1076-1084.

42. Arici S, Karaman S, Dogru S, Cayli S, Arici A, Suren M \& Kaya Z (2014): Central nervous system toxicity after acute oral formaldehyde exposure in rabbits: an experimental study. Human \& experimental toxicology, 33(11), 1141-1149.

43. Devasagayam TPA, Tilak JC, Boloor KK and Sanc KS (2004): Free radicals and antioxidants in human health: current status and future prospects. J Assoc Physiol, India 52: 794-804.

44. Coleshowers, Oguntibeju M, Ukpong \& E.J Truter (2010):Effects of methotrexate on antioxidant enzyme status in a rodent model; Medical Technology SA | Volume 24 No. 1 | June 2010.

45. Pigeolot E, Corbisier P, Houbion A, Lambert D and Michiels C (1990): Glutathione peroxidase, superoxide dismutase and catalase inactivation by peroxides and oxygen derived radicals. Mech Age Dev 1990; 54: 283-297.

46. Arpag H, Mehmet Gül, Yusuf Aydemir, Nurhan Atilla, Birgül Yigitcan, Tugrul Cakir, Cemal Polat, Özer Pehirli (2017): Protective Effects of Alpha-Lipoic Acid on Methotrexate-Induced Oxidative Lung Injury in Rats; Received 31 December 2016; accepted 14 February 2017; Journal of Investigative Surgery Copyright C 2017 Taylor \& Francis Group, LLC ISSN: 0894-1939 print / 1521-0553 online DOI: 10.1080/08941939.2017.1296513

47. Dobrota D, Matejovicova M, Kurella EG \& Boldyrev AA (1999): Na/K-ATPase under oxidative stress: molecular mechanismsofin-jury. Cellular and molecular neurobiology, 19(1), 141-149.

48. Brines $M$ and Cerami A (2006): Discovering erythropoietin's extrahematopoietic functions:biology and clinical promise. Kidney Int. 2006;70:246-250.

49. Kisaoglu A, Borekci B, Yapca OE, Bilen H \& Suleyman H (2013): Tissue damage and oxidant/antioxidant balance. The Eurasian journal of medicine, 45(1), 47.

50. Khurana DS, Valencia I, Goldenthal MJ, Legido A (2013):Mitochondrialdysfunction in epilepsy. Semin. Pediatr.Neurol. 20, 176- 187.

51. Xie N, Wang C, Lian Y, Wu C, Zhang H, Zhang Q (2014): Puerarin Protects Hippocampal Neurons Against Cell Death in Pilocarpine- Induced Seizures Through Antioxidant and Anti-Apoptotic Mechanisms. Cell. Mol. Neurobiol. 34, 1175-1182. 
52. Kudryashova IV, Onufriev MV, Kudryashov IE, Gulyaeva NV (2009):Caspase-3 activity in hippocampal slices reflects changes in synaptic plasticity. Neurosci.Behav. Physiol. 39, 13-20.

53. Engel, T., Tanaka, K., Jimenez-Mateos, E.M., Caballero-Caballero, A., Prehn, J.H.M., Henshall, D.C., 2010. Loss of p53 results in protracted electrographic seizures and development of an aggravated epileptic phenotype following status epilepticus. Cell Death Dis. 1, e79.

54. Jiao, S., Li, Z., (2011).Nonapoptotic Function of BAD and BAX in Long- Term Depression of Synaptic Transmission. Neuron 70,758-772.

55. Ahles TA, Saykin AJ (2007): Candidate mechanisms for chemotherapy-induced cognitive changes. Nat Rev Cancer;7((3)):192-201..

56. Seaton TA, Jenner P \& Marsden CD (1996). Mitochondrial respiratory enzyme function and superoxide dismutase activity following brain glutathione depletion in the rat. Biochemical pharmacology,52(11),1657-1663.

57. Packer L, Tritschler HJ \& Wessel K (1997). Neuroprotection by the metabolic antioxidant $\alpha$-lipoic acid. Free radical biology and medicine, 22(1-2), 359-378.

58. Toklu HZ, Hakan T, Celik H, Biber N, Erzik C, Ogunc AV \&Sener G(2010): Neuroprotective effects of alphalipoic acid in experimental spinal cord injury in rats. The journal of spinal cord medicine, 33(4), 401-409.

59. Memeo A \& Loiero M (2008): Thioctic Acid and Acetyl-L-Carnitine in the Treatment of Sciatic Pain Caused by a Herniated Disc. Clinical drug investigation, 28(8), 495-500.

60. Tomassoni D, Amenta F, Di Cesare Mannelli L, Ghelardini C, Nwankwo IE, Pacini A \& Tayebati SK (2013).Neuroprotective activity of thioctic acid in central nervous system lesions consequentto peripheral nerve injury. BioMed researchinternational,2013.

61. Melli G, Taiana M, Camozzi F, Triolo D, Podini P, Quattrini A and Lauria G (2008): Alpha-lipoic acid prevents mitochondrial damage and neurotoxicity in experimental chemotherapy neuropathy. Experimental neurology, 214(2), 276-284.

62. Ferreira PMP, Militão GCG and Freitas RM (2009): Lipoic acid effects on lipid peroxidation level, superoxide dismutase activity and monoamines concentration in rat hippocampus. Neuroscience letters, 464(2), 131-134
63. Zhao, R. R., Xu, F., Xu, X. C., Tan, G. J., Liu, L. M., Wu, N., and Liu, J. X. (2015). Effects of alphalipoic acid on spatial learning and memory, oxidative stress, and central cholinergic system in a rat model of vascular dementia. Neuroscience letters, 587, 113-119.

64. Fava A, Pirritano D, Plastino M, Cristiano D, Puccio G, Colica C \& Bosco D (2013): The effect of lipoic acid therapy on cognitive functioning in patients with Alzheimer's disease. Journal of neurodegenerative diseases, 2013.

65. Baluchnejadmojarad T, Roghani M, Kamran M and Karimi N (2012):The Effect of Alpha-Lipoic Acid on Learning and Memory Deficit in a Rat Model of Temporal Lobe Epilepsy. Basic and Clinical Neuroscience, 3(3), 58-66.

66. Burnett MG and Zager EL (2004): Pathophysiology of peripheral nerve injury: a brief review. Neurosurgical focus, 16(5), 1-7.

67. Dixit S, Dhar P \& Mehra RD (2015):Alpha lipoic acid (ALA) modulates expression of apoptosis associated proteins in hippocampus of rats exposed during postnatal period to sodium arsenite $(\mathrm{NaAsO} 2)$. Toxicology reports, 2, 78-87.

68. Cetinkaya A, Bulbuloglu E, Kantarceken B, Ciralik $\mathrm{H}$, Kurutas EB, Buyukbese MA and Gumusalan Y (2006): Effects of L-carnitine onoxidant/ antioxidant status in acetic acid-induced colitis. Digestivediseasesand sciences, 51(3), 488-494.

69. Senoglu M, Nacitarhan V, Kurutas EB, Senoglu N, Altun I, Atli Y \& Ozbag D (2009): Intraperitoneal Alpha-Lipoic Acid to prevent neural damage after crush injury to the rat sciatic nerve. Journal of brachial plexus and peripheral nerve injury, 4(1), 22.

70. Mitsui Y, Schmelzer JD, Zollman PJ, Mitsui M, Tritschler HJ and Low PA (1999): Alpha-lipoic acid provides neuroprotection from ischemia-reperfusion injury of peripheral nerve. Journal of the neurological sciences, 163(1), 11-16.

71. Emmez H, Yildirim Z, Kale A, Tönge M, Durdağ E, Börcek AÖ and Baykaner MK (2010): Anti-apoptotic and neuroprotective effects of alpha-lipoic acid on spinal cord ischemia-reperfusion injury in rabbits. Acta neurochirurgica, 152(9), 1591-1601.

72. Wong BS, Brown DR, Pan T, Whiteman M, Liu T, $\mathrm{Bu} \mathrm{X}$ and Sy MS (2001):Oxidative impairment in scrapie-infected mice is associated with brain metals perturbations and altered antioxidant activities.Journal of neurochemistry, 79(3), 689-698. 


\section{الملخص العربى}

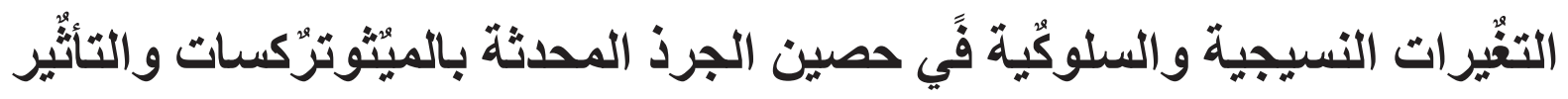 التحسيني المحتمل لحمض ألفا لُّيويّيك

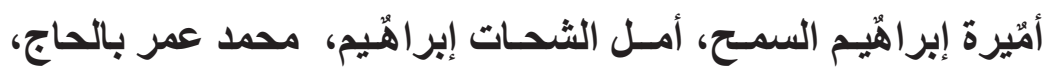 \\ هبه أسـامـة محمـــ}

\section{قسم التشريّيح الآدمي والأجنة ـكلِية الطب - جامعة الزقازِّيق}

المقدمه: المكيثوتريكسات دواء علاجي كيميائي مرتبط بالقصور المعرفي لدي مرضي السرضان الذين عولوجوا بـه. ويشار الي حمض ألفا ليبوك باسم مضاد الاكسدة العالمية بسبب خصائصه الفريدة المضادة للأكسدة الهدف من البحث: در اسة تأثثير الميثوتريكسات علي نسيج الحصين وربطه بضعف الإدر الك وتقييم دور الحماية لحمض ألفليبوك عليه.

المواد والطرق المستخدمة فَي البحث: استخدمت هذه الدراسة اثثان وثلاثون ذكوً را من الفئران البُّيضاء فَي هذه

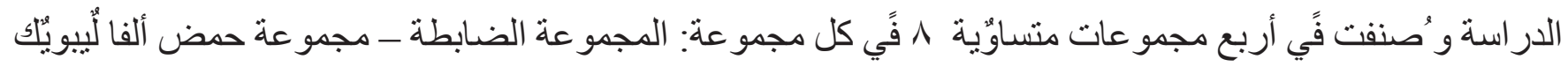

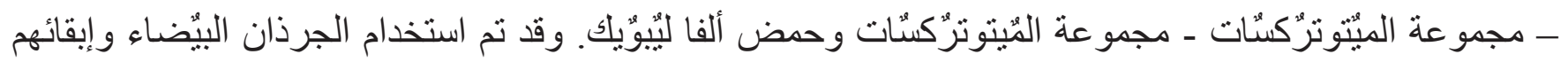
تحت مستوى معايري من الأكل و و وُصنف فَي أربع مجموعات منساوُية م فَي كل مجموعة المجموعة الضابطة: أعطيت و التَّي تلقت محلول فسيولوجي ملحي ومجموعة بحمض ألفا أعطيت . . ب ملجم لكل كيلو جرام عن طرّق

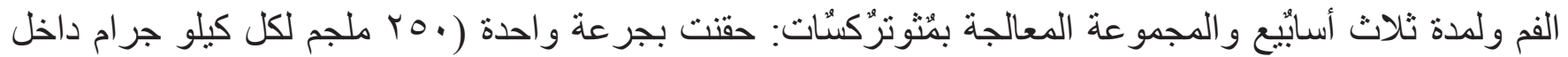

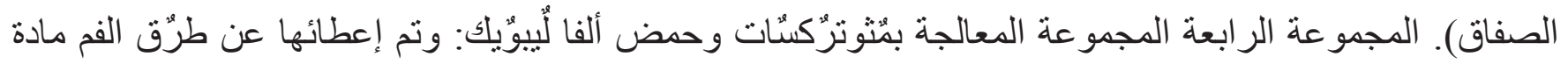

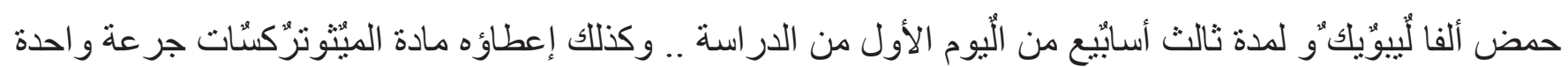
فَّ الْيوم الر ابع من الدر اسة خضعت جمّيع الجرذان للاختبار متاهة موريس المائية لتقيم وظيفة الحصين.عند الانتهاء من مدة التجربة، ثم تم تخديُر الجرذان و استخر اج المخ للإعداد عينات للفحص النسيجي و النسيجي المناعي الكيميائي و الكيميائي الحيوي.

النتائج: سبب الميثوتريكسات استجابة ضعيفة من الجرذان لمتاهة موريس المائية، وسجلت تغير ات كيميائية حيوية و انخفاضا كبير ا في الأنزيمات المؤكسدة وزيادة في مستوي المالوندالداهيد في الأنسجة،علاوة على ذلك شوهدت تغير ات نسيجية في قرن آمون في الجرذان التي تناولت الميثوتريكسات فظهرت خلايا عصبية تنكسيه و أخرى بها علامات الموت المبرمج ، وقد تأكد ذلك بالتحليل المناعي الكيميائي ل GFAP وcaspase -3و التحليل المورفومترى لسُمك طبقة الخلية الهرمية و عدد الخلايا الهرمية، و بإضافة حمض ألفا ليبويك مع الميثونريكسات تحسنت التغيرات النسيجية و الكيميائية النسيجية المناعية و الكيميائية الحيوية بالحصين بصورة و اضحة و أيضا تحسنت سلوكية الجرذان في اختبار متاهة موريس المائية. 
الخلاصة: ثبتت نتائجنا التجربية علي الجرذان البيضاء التأثثر الضار للميثوتريكسات علي انسجة الحصين وكذلك أوضحت الضعف المعرفي المصاحب للعلاج به وأكدت الخصائص المضادة للأكسدة لحمض ألفا ليبوك علي أنسجة الحصين. لذلك يمكن تطبيقه للمرضي بعد إجر اء التقييم السريري المناسب. 